\title{
Mera alanlarında bulunan bitki türleri ve etkileri: Düzce merkez ilçe örneği
}

\author{
Ufuk Akgün AKSAN ${ }^{1}$, Ayşe YAZLIK ${ }^{\text {iD } 2}$ \\ 1Düzce Üniversitesi Fen Bilimleri Enstitüsü, Bitki Koruma Anabilim Dalı, Düzce \\ ${ }^{2}$ Düzce Üniversitesi Ziraat Fakültesi, Bitki Koruma Bölümü, Düzce
}

Bu çalışma; Dr. Ayşe YAZLIK danışmanlığında Ufuk Akgün AKSAN tarafından yürütülmüş olan "Mera alanlarında bulunan bitki türleri ve etkileri: Düzce merkez örneği" isimli Yüksek Lisans Tezinden üretilmiștir.

Alınış tarihi: 21 Eylül 2020, Kabul tarihi: 23 Aralık 2020

Sorumlu yazar: Ayşe YAZLIK, e-posta: ayseyazlik@duzce.edu.tr

\section{$\ddot{0} \mathbf{z}$}

Amaç: $\mathrm{Bu}$ çalışma ile sürdürülebilir mera alanları için yapılabilecek mera ıslahı çalışmalarına kaynak sağlamak ve mera alanlarında bulunan bitkilerin etki durumlarına ve bu etkilerin yönetimine yönelik veriler elde etmek amaçlanmıştır.

Materyal ve Yöntem: Düzce ili merkez ilçe sınırlarındaki mera alanlarında bitki taksonların tespitine yönelik yapılan survey çalışmaları 20192020 yıllarında yürütülmüştür. Merkez ilçe toplam mera alanının \%1'inden az olmayacak şekilde ve ilin doğu, batı, kuzey, güney yöneyleri dikkate alınarak yapılan survey çalışmaları 12 alanda toplam 82 noktada sayımlar şeklinde yapılmıştır.

Araştırma Bulguları: Düzce il merke ilçe sinırlarında bulunan meralarda yapılan surveyler sonucunda; 31 familya'ya bağlı 133 takson tespit edilmiştir. Asteraceae 25 takson ile ilk sırada yer alırken bunu sirasıyla; Poaceae (15 takson) ve Fabaceae (11) takip etmiştir. Yaşam formlarına göre takson dağılımında çok yıllık bitkiler (56 takson) ilk sırada yer alırken, bunu tek yıllık (45) ve iki yıllık (7) bitkiler takip etmiştir. Ayrıca 25 takson çoklu yaşam formuna sahiptir. Mera alanlarında Cynodon dactylon (26.6 bitki/m² - \%90.0), Lamium purpureum (22.6 bitki/m² - \% 82.5), Plantago lanceolata (21.8 bitki/m² - \%90.5) ve Lolium perenne (21.5 bitki/m² $\%$ 94.7) en yaygın taksonlardır. Ayrıca mera alanlarında 72 taksonun farklı yönlerde etkilere sahip olduğu belirlenmiştir. Bu etkilere göre; 29 takson yem değeri olmasına rağmen toksik, 25 takson yüksek toksik, 10 takson yaralanma + yün kalitesi ve 8 takson yaralanma + toksik etkiye sahiptir.

Sonuç: Düzce ili merkez ilçe mera alanları zengin bitki kompozisyonuna sahiptir. Bununla birlikte, her mera alanında farklı olumsuz etkilere sahip önemli sayıda takson tespit edilmiştir. Dolayısıyla mera alanlarında antropojenik etkenlerden kaynaklı riskleri önlemek için yasal düzenlemelerin ve mera denetimlerinin arttırılması, ayrıca bitkilerin etki durumlarına ve potansiyel bitki istilalarına yönelik farkındalık çalıșmalarının yapılması faydalı olacaktır. Veriler aynı zamanda ilgili alanda mera ıslahı konusunda yapılabilecek çalışmalar için kaynak sağlar.

Anahtar kelimeler: Asteraceae, Düzce, etki, mera, Poaceae, sürdürülebilir

The plant species and their impacts in pasture areas: A case study from Düzce central district

\begin{abstract}
Objective: The aimed of this study to provide resources to pasture restoration studies for sustainable pasture areas, to obtain data on the impact of plants in pasture areas and to create suggestions for the management of these impacts.
\end{abstract}

Materials and Methods: Survey studies were carried out in 2019-2020 to determine plant species in pasture areas within the central district of Düzce province. The studies were carried out at 82 points in 12 areas, taking into account the East, West, North and South directions, not less than $1 \%$ of the total pasture area of the city centre district.

Results: As a result of the survey carried out in the pastures in the centre district of Düzce, 133 taxa belonging to 31 families were identified. The families with the most taxa were Asteraceae with 25 taxa, followed by Poaceae (15 taxa) and Fabaceae (11), 
respectively. Perennial plants (56 taxa) take the first place in the distribution of taxa by life forms, followed by one-year (45) and two-year (7) plants. In addition, 25 taxa have multiple life forms. In pasture areas, Cynodon dactylon $\left(26.6 \mathrm{bitki} / \mathrm{m}^{2}\right.$ \%90.0), Lamium purpureum (22.6 bitki/m² - \% 82.5), Plantago lanceolata (21.8 bitki $\left./ \mathrm{m}^{2}-\% 90.5\right)$ and Lolium perenne (21.5 bitki $/ \mathrm{m}^{2}$ - \% 94.7) were the most common taxa. In addition, it was determined that 72 taxa have in different directions impacts in pasture areas. According to these impacts, 29 taxa is toxic, although they have feed value, 25 taxa are high toxic, 10 taxa have injury + wool quality and 8 taxa have injury + toxic impacts.

Conclusion: The pasture areas of the central district of Düzce province have a rich plant composition. However, a significant number of taxa with different adverse impacts have been identified in each rangeland area. In order to prevent risks arising from anthropogenic factors in pasture areas, it will be beneficial to increase legal regulations and pasture controls, as well as to carry out awareness studies on the impact of plants and potential plant invasions. The data also provides resources for the studies that can be done on pasture restoration in the relevant area.

Key words: Asteraceae, Düzce, impact, pasture, Poaceae, sustainable, toxic

\section{Giriş}

İnsan yaşamının sürdürülebilmesi için beslenme en önemli etkendir. Sağlıklı bir beslenme için ise insanların ihtiyaç duyduğu gıdaların başında hayvansal gıdalar gelmektedir. Bir ulusun gelişmişlik düzeyinin belirlenmesinde önemli ölçütlerden biri olarak kabul edilen kişi başına tüketilen günlük protein miktarı dikkate alındığında ise $70 \mathrm{~kg}$ olan bir yetişkin insanın günlük ortalama $70 \mathrm{gr}$ alması gereken proteinin ortalama \% 40'ının hayvansal proteinlerden karşılanması gerekir. Ancak, Türkiye'de hayvansal besinlerden sağlanan protein esas alındığında, Türkiye'nin günlük 26 gram hayvansal protein tüketimi ile dünya genelinde 176 ülke içerisinde 135. sırada yer aldığı bildirilmektedir (Tüzemen, 2018). Bu durumlar dikkate alındığında nüfus artış oranı da ayrı bir önem taşımaktadır. Nitekim Türkiye'deki nüfus artışının yüksek olması (TUIK, 2018) gerek bitkisel gerekse hayvansal gidalara olan gereksinimin artmasına neden olmaktadır. Bu nedenle üretimi kısıtlayan faktörlerin belirlenmesi ve gerekli önlemlerin alınması önemlidir. Bu kapsamda hayvansal üretimde mera alanlarının önemi yadsınamaz bir gerçektir. Özellikle insan beslenmesinde en önemli hayvansal ürün kaynaklarından biri olan ruminant hayvanların beslenmesi büyük ölçüde doğal çayır-mera alanlarına dayanmaktadır (Hatipoğlu ve ark., 2006). Ayrıca mera alanlarının bașta hayvan sağlığı olmak üzere kaliteli kaba yem kaynağına, yaban hayatı için yaşam alanına, karbon ve suyun depolanmasına ve bitki genetik kaynaklarının yerinde korunmasının sürdürülebilirliğine katkıları ile domino etkisi dikkate alındığında ilgili alanların korunması bu ekosistemlerin canlı unsurların korunması anlamına gelmektedir. Ancak dünya yüzeyinde doğal afetler ve istilacı türlere ek olarak antropojenik faktörlerin etkisiyle ilgili alanlar hızla kaybolma tehlikesiyle karşı karşıyadır (IPBES, 2019). Bu durumun temelini, göçler ve işsizlik gibi faktörler etkilerken her geçen gün artan küreselleşme, şehirleşme ve özelleşme de alan kayıplarının yaşanmasında önemli faktörler arasında yer almaktadır. Bu değişimler ise hem gelişmiş hem de gelişmekte olan ülkelerde gıda üretiminde endișelerin oluşmasına ön ayak olmakta ve dolayısıyla gıda üretiminde kendi kendine yeterliliği azaltmaktadır. Belirtilen faktörlerin artışı tarım arazilerinin ve mera alanlarının kaybını hızlandırırken gıda üretimini de aynı hızla düşürmektedir. $\mathrm{Bu}$ durum küresel raporlarda (örneğin; IPBES, 2019) ve / veya çalışmalarda (Holechek, 2001; Carvell, 2002; Driscoll ve ark., 2014; Aksan ve ark., 2019) vurgulanmakta ve alan kaybı durumunun engellenmesine yönelik öneriler sunulmaktadır. Örneğin; Holechek (2001) Amerika Birleşik Devletlerinde meraların; havaalanı, hapishaneler, alışveriş merkezleri, atık imha sahaları, hurdalıklar, kamu binaları vb. farklı kullanımların hizmetine sunulması sonucu hayvanların otlayacağı açık alanların azaldığını ve buna yönelik önlemlerin alınmasını vurgulamıştır. Ancak, her ne kadar hayvansal üretim açısından bol proteine sahip ve kaliteli kaba yem kaynağı olan ve ayrica polinatör böcekler de dâhil biyolojik çeşitliliğin korunmasında büyük rol oynayan, doğal mera alanlarının mevcut durumunun değerlendirilmesi ve korunmasına yönelik önlemlerde artış gözlense de halen yeterli bir düzeyde değildir (IPBES, 2019). Özellikle hayvansal üretimi büyük oranda meraya dayanan Türkiye gibi (Demir ve İptaş, 1996; Tükel ve Hatipoğlu, 2001; Hatipoğlu ve ark., 2006) ülkelerde mera alanlarının varlığı, kalitesi ve verimi hayvansal üretimin ana bileșeni olduğundan ilgili alanların korunması ve 
verimli alanlar olarak kullanımının sürdürülebilirliği özel önem arz etmektedir. Bu nedenlerden dolayı mera alanlarında mevcut bitki türlerinin tespit edilmesi ve ilgili türlere göre önlemlerin alınması sürdürülebilir mera yönetimi için değerli bilgiler sağlar. Ayrıca özellikle mera alanlarında bulunan bitki türlerinin biyolojik çeşitliliğe, çevreye, insan ve hayvan beslenmesi ve sağlığına olan etkileri (Sullivan ve ark., 2010; Seydoșoğlu ve Kökten, 2018; Benthien ve ark., 2018; Aksan ve ark., 2019; FAO, 2016) de dikkate alındığında, mera alanlarında var olan bitki türlerinin belirlenmesi ve belirlenen türlere göre tür kompozisyonlarının sürdürülebilirliğine yönelik tedbirler alınması önemlidir.

Türkiye'de mera alanlarında bitki kompozisyonunun belirlenmesi konusunda pek çok çalışma (Tükel ve Hatipoğlu, 2001; Bilgen ve Özyiğit, 2005; Gökkuş, 2016; Yıldız ve Özyazıcı, 2017) yapılmıştır. Örneğin; Çınar ve ark., (2018) tarafından Adana ili Tufanbeyli ilçesinde yürütülen bir çalıșmada mera alanlarında 55 familya'dan 190 bitki taksonunun tespit edildiği ve incelenen beş köy merasında en fazla takson içeren familyaların sırasıyla Poaceae, Fabaceae ve Asteraceae olarak sıralandığı bildirilmiştir. Bitki tür kompozisyonunun incelendiği çalışmalarda ayrıca mera ıslahı konularında yapılabilecekler konusunda önemli bilgiler de sunulmaktadır. Bu konuda Ünal ve ark., (2012a) Çankırı ili meralarında yaptıkları floristik inceleme sonucunda en fazla Poaceae familyasına bağlı bitki üyelerine rastlanıldığı ve bu familya bağlı bitkilerin mera ıslah çalışmalarında değerlendirilebileceğini vurgulanmaktadır. Ayrıca araştırıcılar tespit edilen diğer türler arasında istila yeteneğine sahip tür sayısının çok olmasının ilgili alanda iyi bir mera yönetimi yapılmadığının bir göstergesi olduğunu belirtmişlerdir.

Türkiye'nin sahip olduğu toplam tarım alanının 14.6 milyon hektarını (\%38) oluşturan çayır (1.45 milyon ha) - mera (13.1 milyon ha) (TUIK, 2016; Çaçan ve Yüksel, 2016) alanlarındaki bitki kompozisyonu; alan kaybı, iklim, mera kullanım şekilleri (örneğin; otlatma rejimleri) gibi faktörlerden büyük oranda etkilenmektedir (Karan ve Başbağ 2017; Seydoşoğlu ve Kökten, 2018; Benthien ve ark., 2018; IPBES, 2019). Özellikle meraları kullanan hayvan türüne, yönetim uygulamalarının şekline, toprak verimlilik durumuna ve özelliklerine göre bitki kompozisyonunda değişimler olabilir (Sullivan ve ark. 2010; Seydoşoğlu, 2015). Bu konuda Bilgen ve Özyiğit (2005); Antalya, Korkuteli ve Elmalı'da doğal mera alanlarında tespit ettikleri bitkiler içerisinde Fabaceae familyasına bağlı bitki türlerinin az olmasının temel nedeninin ağır otlatma (koyun ve keçi otlaması ile)'dan kaynaklandığını bu nedenle de ilgili meralarda Fabaceae'den sadece tek bir türün (Trifolium pratense) tespit edilebildiğini vurgulamışlardır. Ayrıca Kara ve ark. (2012) Kuzeydoğu Anadolu'da meraların büyük bir çoğunluğunun (\%92) düzensiz bir şekilde otlatıldığını ve meraların yüksek oranda (\%87.3) zayıf bitki örtüsüyle kaplı olduğunu kaydetmiştir. Araştırıcılar bu durumun önüne geçebilmek için mera restorasyonlarına ihtiyaç olduğunu, özellikle bölgelere göre adaptasyonu yüksek ve iklimsel özelliklere göre dayanımı olan bitkiler ile mera bitki çeşitliliğinin arttırılması gerektiğini ve ayrıca münavebeli otlatma sistemlerinin uygulanması doğrultusunda bilinçlendirme faaliyetlerine gereksinim olduğunu vurgulamışlardır.

Mera kompozisyonlarının değişiminde önemli faktörlerden biri de iklimsel değişimlerdir. Özellikle yarı kurak bölgelerde bulunan otlak alanları başta olmak üzere çayır mera alanlarının sürdürülebilirliğinde iklim faktörleri önemlidir. Türkiye'de çayır-mera alanları bu bakımdan incelendiğinde, ilgili alanların \% 85'i yarı kurak bölgelerde yer alırken (Altın ve ark.,2011) Düzce gibi neredeyse her mevsim yağış alan, iç yüzey suları (akarsu, dere, çay) fazla olan bölgelerde mevcuttur (Aksan, 2020). Dolayısıyla mera alanlarında bitkisel biyolojik çeşitlilik iklime bağlı olarak farklı değişimler de gösterebilir (Kuşvuran ve ark., 2011; Ünal ve ark., 2012a, 2012b; Benthien ve ark., 2018) ve bu değişime bağlı olarak yapılabilecek uygulamalar da mera tür kompozisyonlarını etkileyebilir.

Türkiye'de mera alanlarında bulunan bitki örtüsünün orijinal kompozisyonlarından daha farklı yapılar geliştirdiği çeşitli çalışmalarda vurgulanmaktadır (Tükel ve Hatipoğlu, 2001; Bilgen ve Özyiğit, 2005; Asav ve ark., 2014; Gür ve Altın, 2015; Sürmen ve ark. 2015; Gökkuş, 2016; Yıldız ve Özyazıcı, 2017). İlgili çalışmalarda orijinal bitki kompozisyonlarının değişimlerinin temel nedenleri arasında; (i) meraların ortak kullanımda olmaları, (ii) bakım ve ıslah çalışmalarının yeterli olmaması, (iii) mera kullanım ve yönetimine dair düzenlemelerin yetersiz kalması ve (iv) üreticilerin ek bir kaynak harcamadan ilgili alanları sınırsız ve kontrolsüz bir şekilde kullanması (örneğin; ağır ve/veya erken otlatma) gibi durumlar 
sıralanmaktadır. Bu gibi faktörler sonucunda ise meralar ekolojik işlevlerini önemli ölçüde yitirebilmekte ve dolayısıyla bitki kompozisyonu değișmektedir. Örneğin; bitki kompozisyonunu en fazla etkileyen unsurlardan biri olan aşırı ve kontrolsüz otlatma sonucunda; mera alanları çoğu kez hayvanların tercih etmedikleri, yemekte zorlandıkları ve hatta zehirli kimyasal maddeler içeren ve meralarda istilacı olarak nitelendirilen bitki toplulukları hakim türler olabilmektedir (Tükel ve Hatipoğlu, 2001; Balabanlı ve ark., 2006; Gökkuş, 2016). Özellikle mera vejetasyon dengesinin bozulması ve hayvanların severek tükettiği yem bitkilerinin azalmasıyla var olan alanlardan yeterince yararlanılamamaktadır (Terzioğlu ve Yalvaç, 2004; Yavuz, 2013; Yıldız ve Özyazıcı, 2017). $\mathrm{Bu}$ nedenle mera kompozisyonunun düzenlenmesi başta hayvan sağlığı olmak üzere yem kaynağının, yaban hayatı için yaşam alanının, karbon ve su depolanmasının, insan beslenmesinin ve bitki genetik kaynaklarının yerinde korunmasının sürdürülebilirliği için önemlidir. $\mathrm{Bu}$ konu arı popülasyonlarındaki düşüşler dikkate alınarak somutlaştırılabilir. Bombus arılarının habitat kullanımları Kuzeybatı Avrupa'daki iyileştirilmemiş otlaklarda araştırılmış ve arıların genel bolluğunu, tür zenginliğini ve yiyecek arama aktivitesini etkileyen habitat özellikleri arasında; çiçekli bitki türlerinin, özellikle Trifolium pratense gibi tercih edilen yem bitkilerinin çeşitliliği ve bolluğu, vejetasyon yapısı ve yüksekliğinin önemli etkenler olduğu ve bu nedenle çayır - mera alanlarının bitkisel çeşitliliğinin arı popülasyolarındaki düşüşlere engel olunmasında büyük rol oynadığı bildirilmiştir (Carvell, 2002).

Türkiye sahip olduğu doğal çayır-mera alanı ile genis bir zenginliğe sahip olmasına rağmen burada belirtilen pek çok faktör nedeniyle bu zenginliği yeterince kullanamamaktadır. Ayrıca koruma ve yönetim konularında da yaşanan eksiklikler nedeni ile mera alanlarının yok olması ve var olan alanlarında bașta bitki kompozisyonunda değișim olmak üzere mera vejetasyon dengesinin bozulması, bitki ve hayvan biyolojik çeşitliliğinin değişimi, yaşam alanlarının azalması, hayvanların severek tükettiği yem bitkileri azalmasıyla var olan alanlardan yeterince yararlanılamaması (Terzioğlu ve Yalvaç, 2004; Hatipoğlu vd., 2006; Kușvuran ve ark. 2011; Yıldız ve Özyazıcı, 2017; Aksan ve ark., 2019) gibi olumsuz etkiler ortaya çıkmaktadır. $\mathrm{Bu}$ durumlara ek olarak ayrıca belirtilmelidir ki, her ne kadar Türkiye'de burada bahsi geçen pek çok çalışma ile mera alanlarında farklı yönlerde çalışmalar yürütülmüş olsa da halen bazı bölgelerde mera alanlarında bir çalışmaya rastlanılmamakta veya yeterli çalışma bulunmamaktadır. $\mathrm{Bu}$ nedenle Türkiye'de bölgesel ve alt bölgesel bazda mera alanlarında var olan bitki türlerinin belirlenmesi, belirlenen türlere göre etki durumlarının tespiti ve yönetim programlarının uygulamaya geçirilmesi gereklidir.

Belirtilen tüm bu durumları dikkate alarak alt bölgesel çapta yürütülmüş olan bu çalıșmada; Düzce'de sürdürülebilir mera alanları için yapılabilecek mera ıslahı ve yönetimi çalışmalarına kaynak sağlayacak veriler elde etmek ve belirlenen olumsuz etkilere göre mera alanlarında yabancı ot statüsü taşıyan (Tepe, 1998) bitkileri belirlemek amaçlanmıştır. Bu amaçla, Düzce ili merkez ilçe sınırları içerisinde yer alan mera alanlarında bitki türleri tespit edilmiş, tespit edilen türlerin potansiyel etkileri incelenmiş ve ayrıca mera kullanımında karşılaşılan olumsuz etki durumları belirlenmiştir. Düzce merkez ilçe mera alanlarında yürütülen bu çalışma ilgili alanlar için ilk kez ele alınmıştır.

\section{Materyal ve Yöntem}

Batı Karadeniz Bölgesinde $40^{\circ} 37^{\prime}$ ile $41^{\circ} 07^{\prime}$ kuzey enlemleri ve $30^{\circ} 49^{\prime}$ ile $31^{\circ} 50^{\prime}$ doğu boylamları arasında yer alan Düzce ilinin (Şekil 1.) toplam yüzölçümü 259.300 hektardır ve sekiz ilçeye sahiptir (Çizelge 1). Bitki coğrafyası açısından Avrupa-Sibirya (Euro-Siberian) flora alanının Öksin alt flora bölgesinde yer alan Düzce ilinde, orman vejetasyonu geniş bir alan kaplamaktadır. Ayrıca etrafı dağlarla çevrili olan ilin tarımsal potansiyelinin büyük bir kısmı 36.000 hektar genişliğinde olan Düzce ovasindadir (Anonim, 2008).

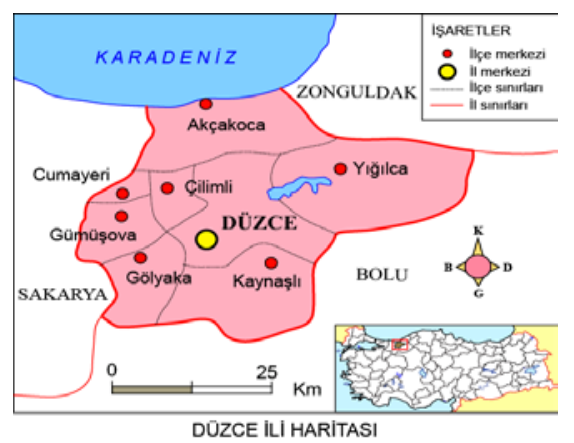

Şekil 1. Düzce İl ve ilçelerinin genel görünümü

Düzce il merkezinde bulunan mera alanlarında 2019-2020 yıllarında bitki türlerini tespit edebilmek için yapılan survey çalışmalarında alınan örnek 
sayısı Düzce merkez ilçede bulunan toplam mera alanının \%1'inden az olmayacak șekilde belirlenmiştir (Yazlık ve ark., 2019). Ancak öncelikle merkez ilçe sınırlarında bulunan toplam köy sayısı (96 köy - Düzce Tarım ve Orman İl Müdürlüğü verileri, 2020), bu alanlara bağlı mera alanlarının büyüklüğü ve yöneyleri dikkate alınmış ve mera alanı 20 dönümden az olan meralar çalışmaya dâhil edilmemiştir. Buna göre 96 alan sayısının \%1 i olan toplam 10 alan belirlenmiş ancak yöneyler (Doğu, Batı, Kuzey, Güney)'de dikkate alınarak toplam 12 alanda (her yöneyden üç alan olacak şekilde) survey çalışmaları yapılmıştır. Surveyi yapılan alanlar ve alınan örnek sayıları Çizelge 1'de sunulmuştur.

Çizelge 1. Survey yapılan Düzce ili merkez ilçe mera alanları ve örnek sayıları

\begin{tabular}{cccccc}
\hline No & Survey Alanları & Alan büyüklüğ̈̈ (dekar) & Örnek sayısı (adet) & Konum & GPS \\
\hline 1 & Duraklar & 60 & 6 & Güney & $40.790860,31.123960$ \\
\hline 2 & Hacıahmetler & 61 & 6 & Güney & $40.803723,31.148820$ \\
\hline 3 & Küçükahmetler & 34 & 3 & Güney & $40.796578,31.133358$ \\
\hline 4 & Kadıŏlu & 121 & 12 & Kuzey & $40.877171,31.122880$ \\
\hline 5 & ${ }^{*}$ Sarayyeri & 69 & 7 & Kuzey & $40.873631,31.135158$ \\
\hline 6 & ${ }^{*}$ Çavușlar & 27 & 3 & Kuzey & $40.871470,31.172558$ \\
\hline 7 & ${ }^{*}$ Ağaköy & 120 & 13 & Batı & $40.830237,31.141866$ \\
\hline 8 & Şaziye & 44 & Batı & $40.843323,31.052190$ \\
\hline 9 & Karadere Hasanağa & 144 & Doğu & $40.847168,31.198928$ \\
\hline 10 & ${ }^{*}$ Yahyalar & 49 & 5 & Doğu & $40.835518,31.219376$ \\
\hline 11 & Gündolaması & 60 & 2067521 \\
\hline 12 & Günbașı & 809 & 2 & Doğu & $40.848945,31.241861$ \\
\hline
\end{tabular}

*Mahalle statüsü kazanmıștır.

Bitkilerin sayımında $1 \mathrm{~m}^{2 \prime}$ lik çerçeveler kullanılmış ve bunun için $50 \mathrm{~cm} \times 50 \mathrm{~cm}$ ebatlarında bir çerçeve her bir örnek alana dört kez atılmıștır. Bitki sayımları sırasında; dar yapraklı türler kardeşleri sayılarak, geniş yapraklı türler ise tüm bitki olarak sayılmıştır. Yabancı otların yoğunluklarının (bitki $/ \mathrm{m}^{2}$ ) belirlenmesi ağırlıklı ortalama esasına göre yapılmıştır. Bunun için bir alanda her bir yabancı ot için yapılan sayımlar sonucu elde edilen değer, ilgili alanda yapılan toplam alana bölünerek hesaplanmıștır. Aynı zamanda yabancı ot türlerinin rastlanma sıklığı (RS) da belirlenmiş̦tir. Bu değer Odum (1971)'a göre aşağıdaki eșitlikle hesaplanmıştır:

$\mathrm{RS}=100 \mathrm{X}(\mathrm{n}) /(\mathrm{m})$ [n: Bir türün bulunduğu ölçüm sayısı - m: Yapılan toplam ölçüm sayısı]

Surveyler 18 Temmuz 2019 - 28 Mayıs 2020 tarihleri aralığında yürütülmüștür. Survey yapılan alanlar içerisinde tespit edilen tüm bitki türlerinin yaşam süreleri (tek yıllık, çok yllık, iki ylllık) için USDA (2020)'dan faydalanılmıştır. Mera alanlarında tespit edilen her bir bitki türünün ayrıca etki durumları insanlar, ruminantlar (geviş getiren hayvanlar), polinatör böcekler (arı, kelebek... vb.) ve diğer canlı grupları (köstebek, solucan, tavşan... vb.) dikkate alınarak incelenmiş ve bu verilere göre genel bir değerlendirme yapılmıştır. Etki durumları; toksik, yaralanma (insan ve/veya hayvanların ağız / deri / tırnakta yaralanma ve/veya tahriş) + yün kalitesine etki yönüyle ele alınmıştır. Tüm veriler çalışma sırasındaki tespit / gözlem ve ayrıca çalışmanın kaynaklarından sağlanmıştır.

Herbaryum çalıșmaları: Survey çalıșmalarında elde edilen bitki örneklerini kurutmak için 38 x $28 \mathrm{~cm}$ boyutlarında ahşap presler kullanılmıştır. Survey sırasında tanınmayan türler tekniğine uygun olarak numaralanarak preslenmiş ve teşhisleri yapılmak üzere laboratuvara getirilmiștir. Toplanan örneklerin teșhisinde (Davis, 1965-1985; Davis vd., 1988) ve Güner vd. (2000) yararlanılmıştır. Ayrıca Latince isimlerin kontrolünde IPNI ( 2020) ve GBIF (2020)'den, bitkilerin Türkçe isimlerinin yazımında ise Uluğ ve ark., (1993) ve Bizim Bitkiler (Güner ve ark., 2012) yararlanılmıştır.

\section{Bulgular ve Tartışma}

Düzce il merkezinde bulunan meralarda yapılan survey ve sayımlar sonucunda 31 familya'ya bağlı 133 takson tespit edilmiştir. Tespit edilen tüm taksonlar ve bu taksonların bağlı bulunduğu familyalar, Türkçe isimleri ve yaşam süreleri Çizelge 2'de sunulmuştur. 

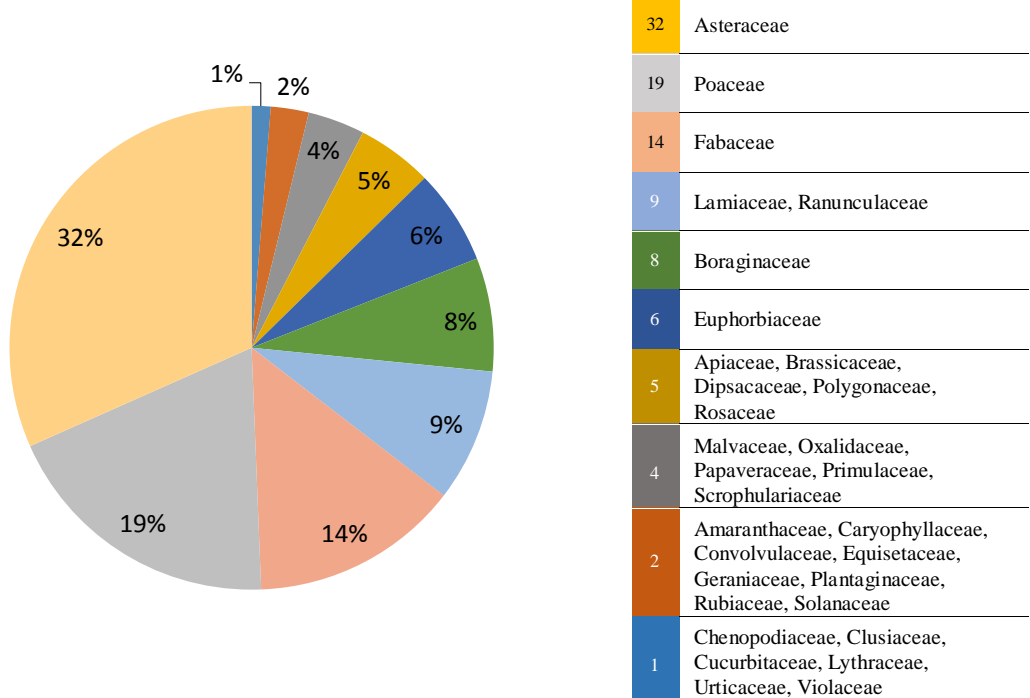

Şekil 2. Mera alanlarında tespit edilen familyaların genel dağılımları (\%)

Mera alanlarında mevcut olan taksonlar familyalar bakımından değerlendirildiğinde; Asteraceae \% 32 oranında bir pay ile ilk sırada yer alırken, bunu Poaceae (\%19), Fabaceae (\%14), Lamiaceae ve Ranunculaceae (\%9), Boraginaceae (\%8), Euphorbiaceae (\%6) ve diğer familyalar (\% 12) takip etmiştir (Şekil 2). Bu veriler, Türkiye genelinde mera alanlarında Aksan ve ark. (2019) tarafindan bildirilen familyalar ile genel olarak paraleldir. Nitekim, Aksan ve ark. (2019) inceledikleri 74 kaynak esere göre; mera alanlarında 51 familyadan 300 takson listelemiş ve bu taksonlara ait familyalar dikkate alındığında; Fabaceae 61 takson ile en fazla bitki barındıran familya iken bunu sırasıyla Asteraceae (42 takson), Poaceae (34), Lamiaceae (16), Ranunculaceae (15) ve Euphorbiaceae (10) familyaları takip etmiştir. Tespit edilen familyalara göre takson sayıları ise Şekil 3'de sunulmuştur. Buna göre en az 5 takson içeren familyalar sıralandığında; Asteraceae 25 takson ile ilk sırada yer alırken bunu
15 takson ile Poaceae, 11 takson ile Fabaceae, 7'șer takson ile Lamiaceae ve Ranunculaceae, 6 takson ile Boraginaceae, 5 takson ile de Euphorbiaceae takip etmiștir.

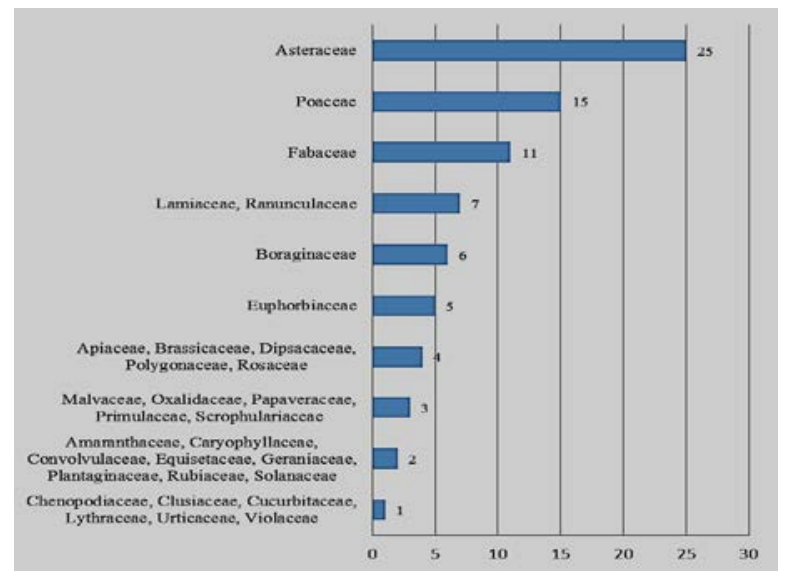

Şekil 3. Familyalara göre takson sayıları

Çizelge 2. Düzce İli Merkez İlçe Mera alanlarında karşılaşılan bitki türleri, türlerin bağlı olduğu familyalar, yaşam süreleri, rastlanma sıklıkları, yoğunlukları ve etkileri A: Tek Yıllık (Annual), B: iki Yıllık (Biannual), P: Çok Yıllık (Perennial)

\begin{tabular}{|c|c|c|c|c|c|c|c|}
\hline Latince ismi & Türkçe ismi & Familya & $\begin{array}{l}\text { Yaşam } \\
\text { süresi }\end{array}$ & $\begin{array}{l}\text { Rastlanma } \\
\text { Sıklığı (\%) }\end{array}$ & $\begin{array}{l}\text { Yoğunluk } \\
\left(\text { bitki } / \mathrm{m}^{2} \text { ) }\right.\end{array}$ & Etkiler & Kaynak \\
\hline Amaranthus retroflexus $\mathrm{L}$. & Horozibiği & Amaranthaceae & A & 12.0 & 2.2 & $\begin{array}{c}\text { Yem değeri var } \\
\text { +Toksik }\end{array}$ & Öztürk ve ark., 2008 \\
\hline Amaranthus albus L. & Kömüşmancarı & Amaranthaceae & A & 4.3 & 0.9 & $\begin{array}{l}\text { Yem değeri var } \\
+ \text { Toksik }\end{array}$ & Öztürk ve ark., 2008 \\
\hline Conium maculatum L. & $\begin{array}{c}\text { Zehirli benekli } \\
\text { baldıran }\end{array}$ & Apiaceae & B & 1.4 & 0.6 & Toksik & $\begin{array}{l}\text { Öztürk ve ark., 2008, Aksan ve } \\
\text { ark., } 2019\end{array}$ \\
\hline Daucus carota L. & Yabanihavuç & Apiaceae & B & 5.3 & 1.1 & - & - \\
\hline Eryngium campestre L. & $\begin{array}{l}\text { Kursenet / } \\
\text { Boğadikeni }\end{array}$ & Apiaceae & $\mathrm{P}$ & 16.3 & 2.8 & $\begin{array}{c}\text { Yaralanma + } \\
\text { Toksik }\end{array}$ & $\begin{array}{c}\text { Öztürk ve ark., 2008, Aksan ve } \\
\text { ark., 2019, Ünal ve ark., } 2012 \text { b, } \\
\text { Yavuz ve ark. } 2012\end{array}$ \\
\hline
\end{tabular}




\section{Çizelge 2. Devamı}

\begin{tabular}{|c|c|c|c|c|c|c|c|}
\hline Oenanthe pimpinelloides L. & Delimaydanoz & Apiaceae & $\mathrm{P}$ & 6.2 & 1.2 & Toksik & Öztürk ve ark., 2008 \\
\hline $\begin{array}{l}\text { Artemisia verlotiorum } \\
\text { Lamotte. }\end{array}$ & Lazyavşanı & Asteraceae & $P$ & 6.3 & 0.8 & Toksik & Öztürk ve ark., 2008 \\
\hline Asteriscus spinosus Sch.Bip. & Diken otu & Asteraceae & A & 4.8 & 0.7 & Yaralanma & Aksan ve ark., 2019 \\
\hline Bellis perennis $\mathrm{L}$. & Koyungözü & Asteraceae & $P$ & 20.5 & 12.3 & $\begin{array}{l}\text { Yem değeri var } \\
\quad+\text { Toksik }\end{array}$ & $\begin{array}{c}\text { Altundağ \& Öztürk, 2011, } \\
\text { Yavuz ve ark., 2012, Aksan ve } \\
\text { ark., 2019 } \\
\end{array}$ \\
\hline Carduus acanthoides L. & Sakadikeni & Asteraceae & B & 8.4 & 1.2 & Yaralanma & - \\
\hline $\begin{array}{l}\text { Centaurea iberica Trevir. } \\
\text { ex Spreng. }\end{array}$ & Deligözdikeni & Asteraceae & $\mathrm{A} / \mathrm{B}$ & 9.3 & 1.1 & Yaralanma & Öztürk ve ark., 2008 \\
\hline Cichorium intybus L. & Hindiba & Asteraceae & $\mathrm{B} / \mathrm{P}$ & 18.2 & 3.4 & $\begin{array}{l}\text { Yem değeri var } \\
\quad+\text { Toksik }\end{array}$ & $\begin{array}{c}\text { Bilgen \& Özyiğit, 2005, Yavuz } \\
\text { ve ark., 2012, Yılmaz, 2018, } \\
\text { Aksan ve ark., } 2019\end{array}$ \\
\hline Cirsium arvense (L.) Scop. & Köygöçüren & Asteraceae & $P$ & 9.3 & 1.4 & $\begin{array}{c}\text { Yaralanma + } \\
\text { Toksik }\end{array}$ & $\begin{array}{c}\text { Yavuz ve ark., 2012, Aksan ve } \\
\text { ark., 2019, Kușkapan, } 2019\end{array}$ \\
\hline Cirsium hypoleucum DC. & Vişnekangalı & Asteraceae & $P$ & 6.3 & 0.7 & Yaralanma & Aksan ve ark., 2019 \\
\hline $\begin{array}{l}\text { Conyza albida Willd. ex } \\
\text { Spreng. }\end{array}$ & Akçakalotu & Asteraceae & $\mathrm{A} / \mathrm{B}$ & 14.2 & 3.3 & - & - \\
\hline $\begin{array}{l}\text { Conyza canadensis (L.) } \\
\text { Cronquist }\end{array}$ & Selviotu & Asteraceae & $\mathrm{A} / \mathrm{B}$ & 20.4 & 3.7 & - & - \\
\hline Inula britannica L. & Çayırandızı & Asteraceae & $P$ & 7.2 & 3.8 & $\begin{array}{c}\text { Yem değeri var } \\
\text { +Toksik }\end{array}$ & \multirow{2}{*}{ Aksan ve ark., 2019} \\
\hline Lactuca serriola L. & $\begin{array}{l}\text { Eşekhelvası / } \\
\text { yabani marul }\end{array}$ & Asteraceae & $\mathrm{A} / \mathrm{B}$ & 8.3 & 1.1 & Yaralanma & \\
\hline Lapsana communis $\mathrm{L}$. & Şebrek & Asteraceae & A & 5.2 & 0.7 & - & - \\
\hline Matricaria chamomilla L. & $\begin{array}{c}\text { Tibbi papatya - } \\
\text { Alman papatyası }\end{array}$ & Asteraceae & A & 10.2 & 4.6 & - & - \\
\hline $\begin{array}{l}\text { Petasites hybridus (L.) } \\
\text { G.Gaertn., B.Mey. \& Scherb. }\end{array}$ & Kabalak & Asteraceae & $P$ & 8.3 & 1.6 & $\begin{array}{c}\text { Yem değeri var } \\
+ \text { Toksik }\end{array}$ & Aksan ve ark., 2019 \\
\hline Picris hieracioides Boiss. & Delişiro & Asteraceae & $\mathrm{B} / \mathrm{P}$ & 17.2 & 5.3 & - & - \\
\hline Senecio vulgaris $\mathrm{L}$. & Taş akçll otu & Asteraceae & $\mathrm{A}$ & 13.2 & 4.4 & $\begin{array}{c}\text { Yem değeri var } \\
\text { +Toksik }\end{array}$ & Aksan ve ark., 2019 \\
\hline $\begin{array}{l}\text { Senecio vernalis Waldst. \& } \\
\text { Kit. }\end{array}$ & Kanaryaotu & Asteraceae & A & 10.5 & 2.3 & $\begin{array}{l}\text { Yem değeri var } \\
\text { +Toksik }\end{array}$ & $\begin{array}{c}\text { Töngel \& Ayan, 2005, } \\
\text { Balabanlı ve ark., 2006, } \\
\text { Yılmaz, 2018, Aksan ve ark., } \\
2019\end{array}$ \\
\hline $\begin{array}{l}\text { Silybum marianum (L.) } \\
\text { Gaertn. }\end{array}$ & Devedikeni & Asteraceae & $\mathrm{A} / \mathrm{B}$ & 6.3 & 3.3 & Yaralanma & \multirow{2}{*}{ Aksan ve ark., 2019} \\
\hline Sonchus asper (L.) Hill & Eşek gevreği & Asteraceae & A & 11.5 & 3.1 & - & \\
\hline $\begin{array}{l}\text { Taraxacum macrolepium } \\
\text { Schischk. }\end{array}$ & Karsçıtlığı & Asteraceae & $P$ & 36.3 & 7.8 & - & - \\
\hline $\begin{array}{l}\text { Tragopogon } \\
\text { buphthalmoides Boiss. }\end{array}$ & Tarlayemliği & Asteraceae & $P$ & 20.6 & 4.4 & - & - \\
\hline Onopordum acanthium L. & Galagan & Asteraceae & B & 12.0 & 3.1 & $\begin{array}{c}\text { Yaralanma + } \\
\text { Toksik }\end{array}$ & Öztürk ve ark., 2008 \\
\hline Xanthium spinosum $\mathrm{L}$. & Pitrak & Asteraceae & A & 20.0 & 5.4 & $\begin{array}{c}\text { Yaralanma + } \\
\text { Toksik }\end{array}$ & Öztürk ve ark., 2008 \\
\hline Xanthium strumarium L. & Büyük pıtrak & Asteraceae & A & 14.2 & 2.3 & $\begin{array}{l}\text { Yaralanma + } \\
\text { Toksik, Yün } \\
\text { kalitesi }\end{array}$ & $\begin{array}{l}\text { Öztürk ve ark., 2008, Aksan ve } \\
\text { ark., } 2019\end{array}$ \\
\hline Anchusa azurea Mill. & Sığırdili & Boraginaceae & $\mathrm{P}$ & 3.1 & 0.6 & Toksik & Aksan ve ark., 2019 \\
\hline Echium vulgare $\mathrm{L}$. & Engerekotu & Boraginaceae & $\mathrm{A} / \mathrm{B} / \mathrm{P}$ & 8.5 & 1.6 & Toksik & Öztürk ve ark., 2008 \\
\hline Heliotropium europaeum L. & Akrep otu & Boraginaceae & $\mathrm{P}$ & 2.6 & 0.7 & - & - \\
\hline Myosotis arvensis (L.) Hill & Kardeşboncuğu & Boraginaceae & $\mathrm{A}$ & 18.7 & 6.9 & - & - \\
\hline $\begin{array}{l}\text { Myosotis laxa subsp. } \\
\text { Caespitosa (Schultz) Hyl. ex } \\
\text { Nordh. }\end{array}$ & Hüthütgözü & Boraginaceae & $\mathrm{A} / \mathrm{B}$ & 11.4 & 3.9 & - & - \\
\hline $\begin{array}{l}\text { Trachystemon orientalis } \\
\text { (L.) D.Don }\end{array}$ & Kaldirik & Boraginaceae & $P$ & 15.6 & 3.4 & - & - \\
\hline $\begin{array}{l}\text { Capsella bursa-pastoris } \\
\text { Medik. }\end{array}$ & Çobançantası & Brassicaceae & A & 25.0 & 7.2 & Toksik & \multirow[t]{2}{*}{ Aksan ve ark., 2019} \\
\hline Cardamine hirsuta L. & Killı kodim & Brassicaceae & A & 19.4 & 1.6 & Toksik & \\
\hline Draba verna $\mathrm{L}$. & Çırçırotu & Brassicaceae & $\mathrm{A}$ & 27.5 & 11.6 & - & - \\
\hline Raphanus raphanistrum L. & Eşek turpu & Brassicaceae & $\mathrm{A} / \mathrm{B}$ & 21.9 & 3.8 & - & - \\
\hline Cerastium fontanum B. & Koruboynuzotu & Caryophyllaceae & $\mathrm{B} / \mathrm{P}$ & 28.1 & 8.5 & - & - \\
\hline Silene latifolia Poir. & Glclgıcl & Caryophyllaceae & $\mathrm{B} / \mathrm{P}$ & 7.50 & 0.7 & Toksik & Öztürk ve ark., 2008 \\
\hline Chenopodium album L. & Ak kazayağı & Chenopodiaceae & $\mathrm{A}$ & 52.0 & 9.2 & Toksik & $\begin{array}{l}\text { Lubenov, 1985, Yavuz ve ark., } \\
\text { 2012, Aksan ve ark., } 2019\end{array}$ \\
\hline Hypericum perforatum $\mathrm{L}$. & Kantaron & $\begin{array}{c}\text { Clusiaceae } \\
\text { (Hypericaceae) }\end{array}$ & $P$ & 12.4 & 4.3 & Toksik & $\begin{array}{l}\text { Töngel ve Ayan, 2005, Öztürk } \\
\text { ve ark., 2008, Yavuz ve ark., } \\
\text { 2012, Aksan ve ark., } 2019\end{array}$ \\
\hline Convolvulus arvensis L. & Tarla sarmaşığı & Convolvulaceae & $\mathrm{P}$ & 60.4 & 4.8 & Toksik & $\begin{array}{l}\text { Yavuz ve ark., 2012, Aksan ve } \\
\text { ark., 2019, Kuşkapan, } 2019\end{array}$ \\
\hline
\end{tabular}


Çizelge 2. Devamı

\begin{tabular}{|c|c|c|c|c|c|c|c|}
\hline $\begin{array}{l}\text { Calystegia sepium (L.) R. } \\
\text { Br. }\end{array}$ & Çitsarmaşı̆̆ı & Convolvulaceae & $\mathrm{P}$ & 5.4 & 0.6 & - & - \\
\hline $\begin{array}{l}\text { Ecballium elaterium (L.) } \\
\text { A.Rich. }\end{array}$ & Eşekhıyarı & Cucurbitaceae & $\mathrm{P}$ & 23.7 & 3.4 & - & - \\
\hline Cephalaria syriaca Schrad. & Pelemir & $\begin{array}{c}\text { Dipsacaceae } \\
\text { (Caprifoliaceae) }\end{array}$ & A & 40.0 & 11.2 & Yün kalitesi & \multirow{2}{*}{ Aksan ve ark., 2019} \\
\hline Dipsacus fullonum L. & Fesçidikeni & $\begin{array}{c}\text { Dipsacaceae } \\
\text { (Caprifoliaceae) }\end{array}$ & B & 4.30 & 1.2 & Yaralanma & \\
\hline Scabiosa columbaria L. & Uyuzotu & $\begin{array}{c}\text { Dipsacaceae } \\
\text { (Caprifoliaceae) }\end{array}$ & $\mathrm{B} / \mathrm{P}$ & 10.5 & 6.6 & - & - \\
\hline $\begin{array}{l}\text { Valerianella locusta (L.) } \\
\text { Laterr. }\end{array}$ & $\begin{array}{c}\text { Nazlı } \\
\text { kuzugevreği }\end{array}$ & $\begin{array}{c}\text { Dipsacaceae } \\
\text { (Caprifoliaceae) }\end{array}$ & A & 68.0 & 4.5 & - & - \\
\hline Equisetum arvense $\mathrm{L}$. & Atkuyruğu & Equisetaceae & $\mathrm{P}$ & 47.0 & 7.2 & $\begin{array}{l}\text { Yem değeri var } \\
\text { +Toksik }\end{array}$ & $\begin{array}{c}\text { Balabanlı ve ark., 2006, Öztürk } \\
\text { ve ark., 2008, Demir ve ark., } \\
\text { 2010, Aksan ve ark., } 2019\end{array}$ \\
\hline Equisetum giganteum L. & Kırk kilitotu & Equisetaceae & $\mathrm{P}$ & 15.6 & 4.8 & $\begin{array}{c}\text { Yem değeri var } \\
\text { +Toksik }\end{array}$ & $\begin{array}{c}\text { Öztürk ve ark., 2008, Aksan ve } \\
\text { ark., } 2019\end{array}$ \\
\hline Euphorbia helioscopia L. & Feribanotu & Euphorbiaceae & A & 66.2 & 8.5 & Toksik & $\begin{array}{c}\text { Töngel \& Ayan, 2005, } \\
\text { Balabanlı ve ark., 2006, } \\
\text { Yılmaz, 2018, Aksan ve ark., } \\
2019 \\
\end{array}$ \\
\hline $\begin{array}{l}\text { Euphorbia seguieriana } \\
\text { Neck. }\end{array}$ & Tasmaotu & Euphorbiaceae & $\mathrm{A}$ & 55.0 & 6.8 & Toksik & \multirow{3}{*}{$\begin{array}{l}\text { Öztürk ve ark., 2008, Aksan ve } \\
\text { ark., } 2019\end{array}$} \\
\hline Euphorbia myrsinites L. & Delisütleğen & Euphorbiaceae & $\mathrm{P}$ & 46.5 & 5.3 & Toksik & \\
\hline Euphorbia stricta L. & Katısütleğen & Euphorbiaceae & $\mathrm{A}$ & 71.2 & 13.7 & Toksik & \\
\hline Mercurialis annua L. & Parşen & Euphorbiaceae & A & 44.0 & 6.5 & Toksik & $\begin{array}{c}\text { Töngel \& Ayan, 2005, } \\
\text { Balabanlı ve ark., 2006, Öztürk } \\
\text { ve ark., 2008, Aksan ve ark., } \\
2019\end{array}$ \\
\hline Astragalus sp. & Geven & Fabaceae & $\mathrm{P}$ & 58.0 & 3.5 & Yaralanma & Aksan ve ark., 2019 \\
\hline Galega officinalis $\mathrm{L}$. & Keçi sedefi & Fabaceae & $\mathrm{P}$ & 15.0 & 1.6 & Toksik & $\begin{array}{c}\text { Keeler ve ark., 1988, Yavuz ve } \\
\text { ark., 2012, Aksan ve ark., } \\
2019,\end{array}$ \\
\hline Glycyrrhiza glabra L. & Meyan & Fabaceae & $\mathrm{P}$ & 5.6 & 0.8 & $\begin{array}{c}\text { Yaralanma }+ \\
\text { Toksik }\end{array}$ & Öztürk ve ark., 2008 \\
\hline Lotus corniculatus L. & Gazelboynuzu & Fabaceae & $\mathrm{P}$ & 78.7 & 16.5 & $\begin{array}{c}\text { Yem değeri var } \\
\text { +Toksik }\end{array}$ & $\begin{array}{l}\text { Ünal ve ark., 2012b, Yavuz ve } \\
\text { ark., 2012, Aksan ve ark., } 2019\end{array}$ \\
\hline $\begin{array}{l}\text { Medicago arabica (L.) } \\
\text { Huds. }\end{array}$ & Benli yonca & Fabaceae & $\mathrm{A}$ & 60.5 & 14.0 & - & - \\
\hline Medicago lupulina L. & Bitçikotu & Fabaceae & $\mathrm{A} / \mathrm{P}$ & 44.4 & 9.8 & - & - \\
\hline Medicago sativa L. & Karayonca & Fabaceae & $\mathrm{A} / \mathrm{P}$ & 59.6 & 18.3 & - & - \\
\hline Trifolium repens $\mathrm{L}$. & Ak üçgül & Fabaceae & $\mathrm{P}$ & 62.0 & 17.5 & - & - \\
\hline Trifolium tomentosum $\mathrm{L}$. & Yünlü yonca & Fabaceae & $\mathrm{A}$ & 45.6 & 8.3 & - & - \\
\hline Trifolium arvense $\mathrm{L}$. & Tarla üçgülü & Fabaceae & $\mathrm{A}$ & 66.0 & 12.6 & - & $\begin{array}{c}\text { Yavuz ve ark., 2012, Çınar ve } \\
\text { ark., 2018, Aksan ve ark., } 2019\end{array}$ \\
\hline Vicia sativa $\mathrm{L}$. & Fiğ & Fabaceae & $\mathrm{A}$ & 46.9 & 12.2 & $\begin{array}{l}\text { Yem değeri var } \\
\text { +Toksik }\end{array}$ & $\begin{array}{c}\text { Gür, 2007, Öztürk ve ark., } \\
\text { 2008, Yavuz ve ark., 2012, } \\
\text { Aksan ve ark., } 2019\end{array}$ \\
\hline Geranium tuberosum L. & Çakmuz & Geraniaceae & $\mathrm{P}$ & 37.5 & 3.8 & $\begin{array}{c}\text { Yem değeri var } \\
\text { +Toksik }\end{array}$ & \multirow{2}{*}{ Aksan ve ark., 2019} \\
\hline Geranium robertianum L. & $\begin{array}{l}\text { Turnagagası - } \\
\text { Dağ itırı }\end{array}$ & Geraniaceae & $\mathrm{A} / \mathrm{B}$ & 42.9 & 3.7 & $\begin{array}{c}\text { Yem değeri var } \\
\text { +Toksik }\end{array}$ & \\
\hline Glechoma hederacea L. & Yernanesi & Lamiaceae & $\mathrm{P}$ & 80.3 & 3.6 & - & - \\
\hline Lamium amplexicaule L. & Baltutan & Lamiaceae & $\mathrm{A} / \mathrm{B}$ & 78.7 & 17.5 & - & - \\
\hline Lamium purpureum L. & Ballıbaba & Lamiaceae & $\mathrm{A}$ & 82.5 & 22.6 & - & - \\
\hline Mentha arvensis L. & Kırnanesi & Lamiaceae & $\mathrm{P}$ & 43.7 & 12.5 & - & - \\
\hline Mentha longifolia (L.) L. & $\begin{array}{l}\text { Pünk - Yabani } \\
\text { nane }\end{array}$ & Lamiaceae & $\mathrm{P}$ & 35.0 & 9.6 & - & - \\
\hline Mentha piperita L. & Nane & Lamiaceae & $\mathrm{P}$ & 22.4 & 8.5 & - & - \\
\hline Salvia verbenaca $\mathrm{L}$. & Elmakekiği & Lamiaceae & $P$ & 53.1 & 4.3 & - & - \\
\hline Lythrum salicaria L. & Hevhulma & Lythraceae & $\mathrm{P}$ & 16.2 & 1.2 & $\begin{array}{l}\text { Yem değeri var } \\
+ \text { Toksik }\end{array}$ & Aksan ve ark., 2019 \\
\hline Althaea officinalis L. & Delihatmi & Malvaceae & $\mathrm{P}$ & 53.1 & 4.2 & - & - \\
\hline Malva neglecta Wallr. & Çobançöreği & Malvaceae & $\mathrm{A} / \mathrm{B} / \mathrm{P}$ & 9.4 & 3.3 & - & - \\
\hline Malva sylvestris $\mathrm{L}$. & Ebegümeci & Malvaceae & $\mathrm{A} / \mathrm{B} / \mathrm{P}$ & 23.7 & 4.6 & - & - \\
\hline Oxalis articulata Savigny & Pembeekşiyonca & Oxalidaceae & $\mathrm{P}$ & 77.8 & 15.4 & $\begin{array}{c}\text { Yem değeri var } \\
\text { +Toksik }\end{array}$ & $\begin{array}{l}\text { Öztürk ve ark., 2008, Aksan ve } \\
\text { ark., } 2019\end{array}$ \\
\hline Oxalis corniculata $\mathrm{L}$. & Sarıekşiyonca & Oxalidaceae & $\mathrm{A} / \mathrm{P}$ & 63.4 & 12.7 & $\begin{array}{l}\text { Yem değeri var } \\
+ \text { Toksik }\end{array}$ & Aksan ve ark., 2019 \\
\hline Oxalis pes-capre $\mathrm{L}$. & Koca ekşiyonca & Oxalidaceae & $\mathrm{P}$ & 77.3 & 13.8 & $\begin{array}{c}\text { Yem değeri var } \\
\text { +Toksik }\end{array}$ & $\begin{array}{c}\text { Töngel \&Ayan, 2015, Aksan ve } \\
\text { ark., } 2019 \\
\end{array}$ \\
\hline Chelidonium majus L. & Kırlangıç otu & Papaveraceae & B & 8.2 & 1.4 & Toksik & $\begin{array}{c}\text { Balabanlı ve ark., 2006,Demir } \\
\text { ve ark., 2010, Aksan ve ark., } \\
2019\end{array}$ \\
\hline
\end{tabular}


Çizelge 2. Devamı

\begin{tabular}{|c|c|c|c|c|c|c|c|}
\hline Fumaria officinalis $\mathrm{L}$. & Şahtere & Papaveraceae & A & 31.2 & 4.8 & $\begin{array}{l}\text { Yem değeri var } \\
\quad+\text { Toksik }\end{array}$ & $\begin{array}{c}\text { Töngel \& Ayan, 2005, } \\
\text { Balabanlı ve ark., 2006, } \\
\text { Yılmaz, 2018, Aksan ve ark., } \\
2019 \\
\end{array}$ \\
\hline Fumaria capreolata L. & Keçi şahteresi & Papaveraceae & $\mathrm{P}$ & 21.9 & 3.3 & $\begin{array}{l}\text { Yem değeri var } \\
+ \text { Toksik }\end{array}$ & Aksan ve ark., 2019 \\
\hline Plantago lanceolata $\mathrm{L}$. & $\begin{array}{l}\text { Dar yapraklı } \\
\text { sinirli ot }\end{array}$ & Plantaginaceae & $\mathrm{A} / \mathrm{B} / \mathrm{P}$ & 90.5 & 21.8 & $\begin{array}{l}\text { Yem değeri var } \\
\quad+\text { Toksik }\end{array}$ & $\begin{array}{c}\text { Bilgen ve Özyiğit, 2005, Yavuz } \\
\text { ve ark., 2012, Çetiner ve ark. } \\
\text { 2015, Alay ve ark., 2016, } \\
\text { Aksan ve ark., } 2019\end{array}$ \\
\hline Plantago major L. & Sinirotu & Plantaginaceae & $\mathrm{P}$ & 33.2 & 4.8 & $\begin{array}{l}\text { Yem değeri var } \\
\text { +Toksik }\end{array}$ & Aksan ve ark., 2019 \\
\hline $\begin{array}{l}\text { Alopecurus myosuroides } \\
\text { Huds. }\end{array}$ & Tarlatilkikuyruğu & Poaceae & A & 30.6 & 23.1 & - & - \\
\hline Avena sativa $\mathrm{L}$. & Yulaf & Poaceae & $\mathrm{A}$ & 56.1 & 6.3 & - & - \\
\hline Bromus inermis Leyss. & Kılçılksız brom & Poaceae & $\mathrm{P}$ & 22.0 & 10.7 & - & - \\
\hline Bromus japonicus Thunb. & Japon bromu & Poaceae & $\mathrm{A}$ & 15.6 & 1.1 & - & - \\
\hline Cynodon dactylon (L.) Pers. & Köpekdișiayrı̆̆̆ & Poaceae & $\mathrm{P}$ & 90.0 & 26.6 & - & - \\
\hline $\begin{array}{l}\text { Echinochloa crus-galli (L.) } \\
\text { P.Beauv. }\end{array}$ & Darican & Poaceae & A & 46.9 & 6.2 & - & - \\
\hline $\begin{array}{l}\text { Echinochloa colona (L.) } \\
\text { Link }\end{array}$ & Cinek & Poaceae & A & 37.5 & 4.8 & - & - \\
\hline Festuca ovina L. & Koyun yumağı & Poaceae & $\mathrm{P}$ & 51.9 & 10.7 & - & - \\
\hline Hordeum murinum L. & Pisipisiotu & Poaceae & $\mathrm{A}$ & 79.3 & 10.4 & - & - \\
\hline Lolium perenne L. & Çim & Poaceae & $\mathrm{A} / \mathrm{P}$ & 94.7 & 21.5 & - & - \\
\hline Poa bulbosa L. & $\begin{array}{c}\text { Yumrulu } \\
\text { salkımotu }\end{array}$ & Poaceae & $\mathrm{P}$ & 50.0 & 11.6 & - & - \\
\hline Poa annua L. & Yıllıksalkımotu & Poaceae & $\mathrm{A}$ & 63.7 & 23.5 & - & - \\
\hline Poa pratensis L. & Çayırsalkımotu & Poaceae & $\mathrm{P}$ & 25.5 & 7.6 & - & - \\
\hline Setaria glauca (L.) P.Beauv. & Sıçansaçı & Poaceae & $\mathrm{A}$ & 12.4 & 1.5 & - & - \\
\hline Setaria viridis (L.) P.Beauv. & Yeşilsıçansaçı & Poaceae & $\mathrm{A}$ & 23.1 & 3.3 & - & - \\
\hline Polygonum aviculare L. & Köyotu & Polygonaceae & $\mathrm{A}$ & 66.2 & 3.2 & - & - \\
\hline $\begin{array}{l}\text { Polygonum cognatum } \\
\text { Meisn. }\end{array}$ & Madımak & Polygonaceae & $P$ & 53.1 & 4.2 & - & - \\
\hline $\begin{array}{l}\text { Rumex conglomeratus } \\
\text { Murray }\end{array}$ & Ekşi kulak & Polygonaceae & $P$ & 49.4 & 6.3 & $\begin{array}{c}\text { Yem değeri var } \\
\text { +Toksik }\end{array}$ & \multirow{4}{*}{$\begin{array}{l}\text { Öztürk ve ark., 2008, Aksan ve } \\
\text { ark., } 2019\end{array}$} \\
\hline Rumex crispus L. & Labada & Polygonaceae & $\mathrm{A} / \mathrm{B}$ & 54.7 & 5.6 & $\begin{array}{l}\text { Yem değeri var } \\
+ \text { Toksik }\end{array}$ & \\
\hline $\begin{array}{l}\text { Anagallis arvensis var. } \\
\text { caerulea Gouan }\end{array}$ & Farekulağı & Primulaceae & A & 66.9 & 14.4 & $\begin{array}{l}\text { Yem değeri var } \\
\text { +Toksik }\end{array}$ & \\
\hline $\begin{array}{l}\text { Anagallis arvensis var. } \\
\text { arvensis } \mathrm{L} .\end{array}$ & Farekulağı & Primulaceae & $\mathrm{A}$ & 60.0 & 10.7 & $\begin{array}{l}\text { Yem değeri var } \\
\text { +Toksik }\end{array}$ & \\
\hline Primula veriş L. & Tutya & Primulaceae & $\mathrm{P}$ & 8.1 & 0.7 & - & - \\
\hline Adonis aestivalis $\mathrm{L}$. & Kandamlası & Ranunculaceae & $\mathrm{A}$ & 3.2 & 0.3 & - & - \\
\hline $\begin{array}{l}\text { Consolida orientalis (J.Gay) } \\
\text { Schrödinger }\end{array}$ & Morçiçek & Ranunculaceae & A & 13.2 & 2.1 & - & - \\
\hline Helleborus orientalis Lam. & Çöpleme & Ranunculaceae & $\mathrm{P}$ & 34.6 & 2.3 & Toksik & $\begin{array}{c}\text { Töngel \& Ayan, 2005, Aksan } \\
\text { ve ark., } 2019 \\
\end{array}$ \\
\hline Ranunculus brutius Ten. & Buladanotu & Ranunculaceae & $\mathrm{P}$ & 15.0 & 1.0 & Toksik & \multirow{4}{*}{$\begin{array}{c}\text { Töngel \& Ayan, 2005, } \\
\text { Balabanlı ve ark., 2006, Öztürk } \\
\text { ve ark., 2008, Aksan ve ark., } \\
2019\end{array}$} \\
\hline Ranunculus arvensis L. & $\begin{array}{l}\text { Tarla düğün } \\
\text { çiçeği }\end{array}$ & Ranunculaceae & $\mathrm{A} / \mathrm{B}$ & 22.3 & 2.8 & Toksik & \\
\hline $\begin{array}{l}\text { Ranunculus neapolitanus } \\
\text { Ten. }\end{array}$ & Çiçeğezer & Ranunculaceae & $\mathrm{P}$ & 14.6 & 1.1 & Toksik & \\
\hline $\begin{array}{l}\text { Ranunculus marginatus } \\
\text { d'Urv. }\end{array}$ & Çırnıkotu & Ranunculaceae & $P$ & 6.2 & 0.8 & Toksik & \\
\hline Filipendula ulmaria (L.) M.. & Çayırkraliçesi & Rosaceae & $\mathrm{P}$ & 26.3 & 4.8 & - & - \\
\hline Potentilla reptans $\mathrm{L}$. & Reşatınotu & Rosaceae & $\mathrm{P}$ & 44.8 & 8.7 & - & - \\
\hline Rubus canescens DC. & Çobankösteği & Rosaceae & $\mathrm{P}$ & 10.5 & 1.3 & Yaralanma & Aksan ve ark., 2019 \\
\hline Sanguisorba minor Scop. & Çayır düğmesi & Rosaceae & $P$ & 18.4 & 3.2 & - & $\begin{array}{c}\text { Bilgen ve Özyiğit, 2005, Yavuz } \\
\text { ve ark., 2012, Çınar ve } \\
\text { ark.,2018, Aksan ve ark., } 2019\end{array}$ \\
\hline Galium aparine $\mathrm{L}$. & $\begin{array}{l}\text { Çobansüzgeci / } \\
\text { Yoğurtotu }\end{array}$ & Rubiaceae & $\mathrm{P}$ & 19.3 & 2.2 & $\begin{array}{c}\text { Yaralanma + } \\
\text { Toksik }\end{array}$ & $\begin{array}{c}\text { Töngel \& Ayan, 2005, } \\
\text { Balabanlı ve ark., 2006, Öztürk } \\
\text { ve ark., 2008, Aksan ve ark., } \\
2019 \\
\end{array}$ \\
\hline Galium verum $\mathrm{L}$. & $\begin{array}{l}\text { Sarı çiçekli } \\
\text { yoğurt otu }\end{array}$ & Rubiaceae & $\mathrm{P}$ & 18.2 & 1.4 & $\begin{array}{l}\text { Yaralanma + } \\
\text { Toksik }\end{array}$ & $\begin{array}{c}\text { Töngel \& Ayan, 2005, } \\
\text { Balabanlı ve ark., 2006, Öztürk } \\
\text { ve ark., 2008, Ünal ve ark., } \\
\text { 2012b, Aksan ve ark., } 2019 \\
\end{array}$ \\
\hline $\begin{array}{l}\text { Scrophularia scopolii } \\
\text { Hoppe ex Pers. }\end{array}$ & Elköpürten & Scrophulariaceae & $\mathrm{B} / \mathrm{P}$ & 19.3 & 2.4 & $\begin{array}{l}\text { Yem değeri var } \\
\text { +Toksik }\end{array}$ & Öztürk ve ark., 2008 \\
\hline $\begin{array}{l}\text { Verbascum lasianthum } \\
\text { Boiss. ex Benth. }\end{array}$ & Sığırkuyruğu & Scrophulariaceae & B & 16.3 & 0.8 & $\begin{array}{c}\text { Yem değeri var } \\
\text { +Toksik }\end{array}$ & $\begin{array}{l}\text { Yavuz ve ark., 2012, Aksan ve } \\
\text { ark., 2019 }\end{array}$ \\
\hline Veronica hederifolia $\mathrm{L}$. & Baharmavisi & Scrophulariaceae & $\mathrm{A}$ & 74.2 & 14.3 & - & - \\
\hline
\end{tabular}


Çizelge 2. Devamı

\begin{tabular}{|c|c|c|c|c|c|c|c|}
\hline Datura stramonium L. & Boruçiçeği & Solanaceae & A & 32.4 & 2.7 & Toksik & $\begin{array}{c}\text { Balabanlı ve ark., 2006, Öztürk } \\
\text { ve ark., 2008, Aksan ve ark., } \\
2019\end{array}$ \\
\hline Solanum nigrum L. & Köpek üzümü & Solanaceae & A & 37.2 & 1.8 & Toksik & $\begin{array}{l}\text { Töngel \& Ayan, 2005, Öztürk } \\
\text { ve ark., 2008, Aksan ve ark., } \\
2019\end{array}$ \\
\hline Urtica urens L. & Cllağan & Urticaceae & A & 12.3 & 2.1 & $\begin{array}{c}\text { Yem değeri var } \\
\text { +Toksik }\end{array}$ & Aksan ve ark., 2019 \\
\hline Viola odorata L. & Kokulumenekșe & Violaceae & $\mathrm{P}$ & 15.2 & 10.7 & - & - \\
\hline
\end{tabular}

Yaşam formlarına göre takson dağılımları incelendiğinde; çok yıllık yaşam formuna sahip taksonlar \% 42'lik bir oran ile ilk sırada yer almıștır. Ayrıca, \% 34 oranında tek yıllık, \% 5 iki yıllık ve \% 19 oranında ise çoklu yaşam formuna sahip taksonlar belirlenmiştir (Şekil 4). Farklı bir ifade ile yaşam formlarına göre 56 takson çok yıllık yaşam formu ile ilk sırada yer alırken bunu tek yıllık 45 takson ve iki yıllık 7 takson takip etmiştir. Belirlenen 25 takson ise çoklu yașam formuna sahiptir. Aksan ve ark., (2019) Türkiye genelinde incelediği 300 taksona ait yaşam formunda da en fazla çok yıllık (184 takson) bitkilerin mera alanlarında yayılış gösterdiğini ve bunu sırasıyla, tek yıllık (85), iki yıllık (9) ve çoklu yaşam süresine (22) sahip bitki gruplarının takip ettiğini bildirmiştir. $\mathrm{Bu}$ sonuç da Düzce ili merkez ilçe mera alanlarında rastlanılan taksonların yaşam sürelerinin bulunma şekline benzerdir. Bu durum Türkiye'de mera alanlarının genel olarak çok yıllık bitkiler tarafından kurulduğunu ve bu nedenle bitki kompozisyon yapısının değişiminde çok yıllık bitkilerin payının yüksek olabileceğinin de bir göstergesidir. $\mathrm{Bu}$ nedenle özellikle istila potansiyeli yüksek çok yıllık taksonların mera alanlarında kontrolünün mutlak gerekliliğini de ortaya koymaktadır.

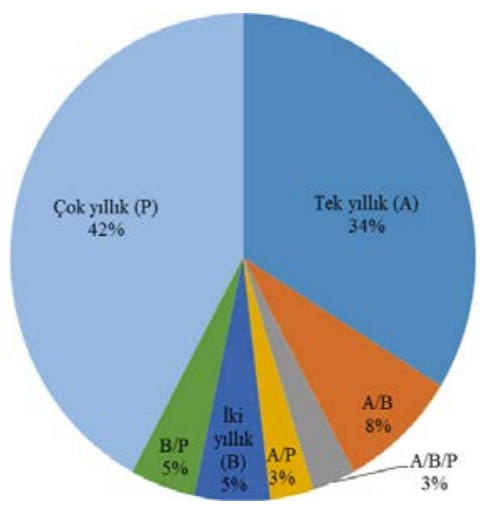

Şekil 4. Yaşam formlarına göre taksonların dağılımı

Taksonların metrekarede bulunma sayıları ve rastlanma sıklıkları Çizelge 2.'de sunulmuştur. Bu değerler metre karede en fazla rastlanılan taksonlara göreincelendiğinde; 26.6 bitki $/ \mathrm{m}^{2}$ ile Cynodon dactylon (\%90.0) ilk sirada yer alırken bunu 22.6 bitki/m² ile Lamium purpureum (\% 82.5), 21.8 bitki/m² Plantago lanceolata (\%90.5), 21.5 bitki/m² Lolium perenne (\% 94.7) ve 17.5 bitki/m² ile Lamium amplexicaule (\% 78.7) takip etmiştir. Yüksek yaygınlık oranlarına sahip olan bu türlerin bir kısmı mera alanlarında etki durumlarına göre farklı şekillerde değerlendirilebilir. Örneğin; Lamium purpureum ( $\%$ 82,5) bitkisinin mera alanındaki varlığı polinatör böcekler için yem kaynağıdır, dolayısıyla olumlu bir etkiye sahiptir (Çizelge 2). Ayrica mera alanlarında rastlanılan; Onopordum acanthium L. (\%12), Xanthium spinosum L. (\%20), Eryngium campestre L. $(\% 16,3)$ ve Chenopodium album L. (\%52) gibi bazı bitki türlerinin yaygınlı̆̆l, en sık rastlanılan taksonlara göre daha az olsa da ruminantları olumsuz etkilemesi ve istila potansiyelleri bu türlerin ilgili alanlarda yabancl ot olarak değerlendirilmesini sağlar. Nitekim mera alanlarında yabancı ot kavramı diğer kültür alanlarında bahsi geçen yabancı ot kavramından çok farklı bir statüde yer alır ve şartlara bağlı olarak yabancı ot tanımı kazanır (Tepe, 1998). Bu nedenle ilgili mera alanlarında yabancı otlar zarar / olumsuz etki durumları dikkate alınarak değerlendirilmiștir. Buna göre; tespit edilen 133 toksonun etki durumları incelenmiş ve 72 taksonun toksik, yaralanma ve yün kalitesini bozma etki durumlarını taşıdığı belirlenmiştir. Bu etkiler incelendiğinde; 29 takson yem değeri olmasına rağmen toksik (\% 22), 25 takson toksik (\% 19), 10 takson yaralanma + yün kalitesi (\% 7) ve 8 takson'da ise yaralanma + toksik (\% 6) etkilere sahip olduğu belirlenmiştir (Çizelge 2, Şekil 5, Şekil 6). Dolayısıyla mera alanlarında ilgili olumsuz etki yönü belirlenen 72 taksonun tamamı yabancı ot olarak değerlendirilebilse de toksik özellikli olan bitkiler (Çizelge 2) fenolojik dönemlerine göre toksik özelliğe sahip olabilir (Lubenov, 1985) ve ilgili alanlar için yabancı ot statüsü de dönemsel olarak değişim gösterebilir. Ayrıca ilgili etki durumları dışında mera alanlarında belirlenen 61 takson ( $\% 46)$ ise ruminantlar ve polinatör böcekler başta olmak üzere mera alanından yararlanan canlılar için yem değeri olan 
türlerdir. Ancak bu taksonlar tek tip yüksek tüketimler sonucu meradan yararlanan canlılara toksik etki de gösterebilir. Nitekim bitkiler içerdikleri allelokimyasallar nedeni ile canlılar için toksik olma yeteneğine sahiptir (Yazlık ve ark., 2020). Dolayısıyla mera alanlarında bitki kompozisyonunun korunması ve yönetimi faaliyetlerinde allelopatik etkileşimlerin önemi ve mera alanlarından faydalanan insan ve hayvanların ise sosyo-ekonomik etki durumları dikkate alınmalıdır.

- Yem değeri var (tek tip yüksek tüketimde toksisite gösterebilir)

- Yem değeri var + Toksik

Toksik

- Yaralanma + Yün kalitesi

- Yaralanma + Toksik

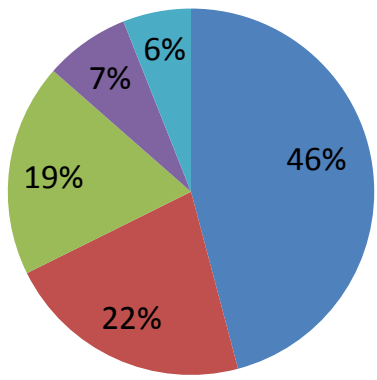

Şekil 5. Taksonların etki durumlarına göre dağılımı

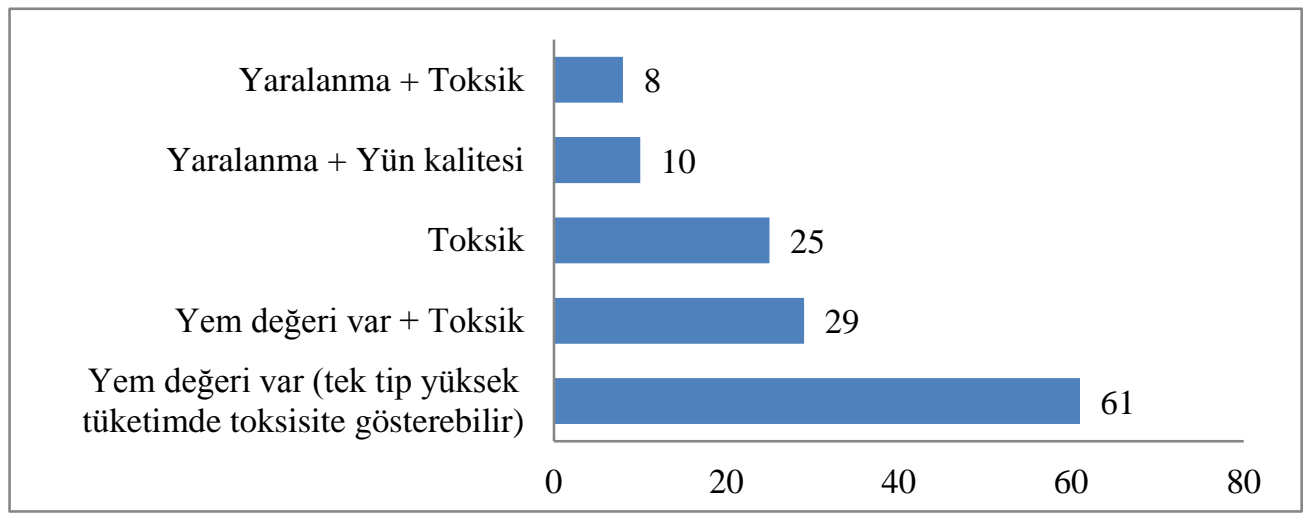

Şekil 6. Etki durumlarına göre belirlenen takson sayıları

Nitekim bitkilerin etkileri konusunda yapılan farklı çalışmalarda (Töngel ve ark., 2005; Öztürk ve ark., 2008; Yazlık ve ark., 2019; Aksan ve ark., 2019) sadece mera alanlarında değil, yabani bitki türlerinin yaygın olarak bulunduğu tarımsal alanlar, antik kentler, kampüs alanları gibi pek çok alanda oluşan etki durumlarına göre tedbirlerin alınması ve yönetim faaliyetlerin bu doğrultuda geliștirilmesinin önemi vurgulanmıştır. Örneğin; Öztürk ve ark., (2008) Türkiye ve Kuzey Kıbrıs zehirli bitkilerin etnoekolojisi konusunda yaptıkları bir çalışmada 48 familyaya bağlı 182 taksonun zehirli bitki statüsünde dahil olduğu bildirilmiştir. Araştırıcılar ayrıca bu taksonlar içerisinde en riskli toksisitenin; Equisetum arvense, Juniperus excelsa, Adonis aestivalis, Ranunculus sceleratus, Agrostemma githago, Peganum harmala, Lathyrus sativus, Vicia sativa, Sambucus nigra, Nicotiana glauca, Digitalis ferruginea, Euphorbia cyparissias, Lolium temulentum, Rumex acetosella, Conium maculatum, Apocynum venetum, Nerium oleander, Cionura erecta, Cannabis sativa, Viburnum lantana, Artemisia absinthium, Tanacetum vulgare ve Ecballium elaterium taksonlarına ait olduğunu vurgulamıșlardır. Surveylerin yapıldığı Düzce ili merkez meralarının tamamında bünyesinde zehirli kimyasal bulunduran bitki türleri mevcuttur. Çalışmanın yapıldığ $ı$ duraklarda en fazla rastlanan taksonlar arasında yer alan Euphorbia cinsine bağlı üyeler ve Lythrum salicaria (Lythraceae) gibi çok yaygın olmayan bazı bitkiler toksik (Öztürk vd., 2008; Kleppel ve LaBarge, 2011; Aksan vd. 2019) etkilere örnek olarak verilebilir. Ancak bu noktada vurgulanması gerekir ki mera alanlarında toksik olarak tespit edilen bitki türlerinin bir kısmı hariç (örneğin; Euphorbiaceae familyasında Euphorbia 
cinsine bağlı taksonlar) olsa da pek çok taksonun toksisitesi mevsimler ve bitkilerin fenolojik dönemlerine göre değişim sergileyebilir (Lubenov, 1985; Öztürk ve ark., 2008; Aksan ve ark., 2019). Nitekim bitkiler merada otlayan hayvanlar başta olmak üzere kullanıldıkları dönemde toksik bileşiklerin oranı az veya henüz üretim aşamasında olabilir. Bu da ilgili bitkilerin mera alanlarında varlığını tehdit etmeyebilir. Bu nedenle bitkilerin mevsimlere ve hatta aylara göre hangi fenolojik dönemde toksik bileşik ihtiva ettiklerine yönelik bilgiler / çalışmalar gerektirmektedir.

Düzce ili merkez ilçeye bağlı mera alanlarının biyolojik çeşitliliği dikkate alındığında tespiti yapılan çiçekli bitki türlerinin tamamı polinatör böcek türlerinin beslenmesi ve bu böcek türlerinin sürdürülebilirliği için yüksek önem taşımaktadır (Deveci ve ark. 2015). Özellikle bu çalışmada da tespit edilen Lamiaceae, Asteraceae ve Fabaceae gibi çekici çiçeklere ve aromatik özelliklere sahip bitkiler özel önem taşımaktadır. Bu bağlamda Deveci ve ark., (2015) Karadeniz bölgesinin Ordu İlinde 2000 ha'llk alanda $(110-300 \mathrm{~m})$ polen kaynağı bakımından en önemli otsu bitki türlerini; Trifolium repens (Fabaceae), Laurocerasus officinalis (Rosaceae), Taraxacum officinale ve Bellis perennis, (Asteraceae), Veronica persica (Scrophulariaceae), Salvia verticillata (Lamiaceae) ve Sinapis arvensis (Brassicaceae) olarak sıralamışlardır. Araştırıcılar ayrıca bu otsu bitkilerinin ve bu bitkilere bağlı familyaların bal arılarının polen kaynağı olarak tercih ettiğini ve ayrıca odunsu (ör.; Juglans regia, Carpinus betulus), ağaççık- çalı (ör.; Pyracantha coccinea) ve sarllıcl (ör.; Vinca major) yaşam formunda olan bitki türlerinin de polen kaynağı açısından önemli olduğunu vurgulamışlardır.

$\mathrm{Bu}$ olumlu etkinin yanında insan beslenmesinde önemli bir paya sahip olan ruminant hayvanlar başta olmak üzere mera alanlarında beslenen diğer hayvan türleri için Eryngium campestre, Carduus acanthoides, Centaurea iberica, Cirsium arvense, Cirsium hypoleucum, Silybum marianum, Onopordum acanthium ve Xanthium spinosum gibi bazı bitkiler "yaralanma ve/veya toksik etkilere (Çizelge 2) sahip olmalarından dolayı mera alanları için önemli riskler taşımaktadır. Ayrıca bu özelliğe sahip taksonlar yüksek çoğalma ve yayılım yetenekleri ile baskın türler olarak mera alanlarının bitki çeşitliliği üzerinde de olumsuz etkiler sergileyebilir. Bu durum mera sürdürülebilirliği bakımından da olumsuz bir etkinin oluşmasına ve sağlıklı mera kompozisyonlarının bozulmasına neden olmaktadır. Örneğin; Ağaköy mera alanında Cirsium arvense, Cirsium hypoleucum, Eryngium campestre, Onopordum acanthium, Xanthium spinosum, Xanthium strumarium gibi bitki taksonlarının yüksek yayılımları mera kompozisyonunun büyük oranda etkilediği Şekil 7'da sunulmuştur. Bu nedenle Düzce merkez ilçe sınırlarında yer alan meralar da yüksek yayılım sergileyen taksonların yönetimi için gerekli çalışmalara bir an önce başlanmalıdır.

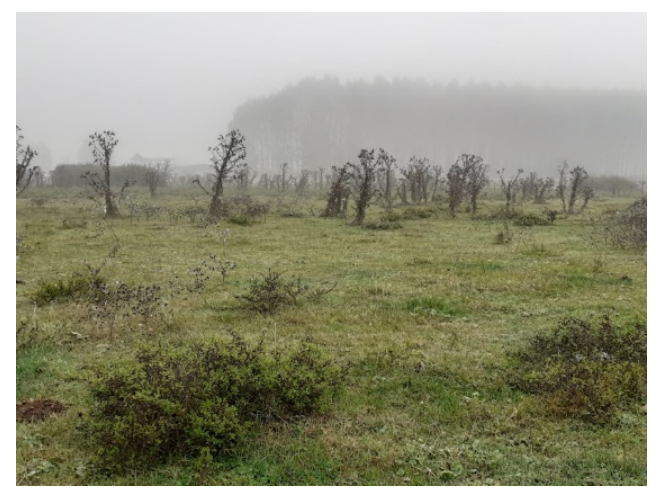

Şekil 7. Ağaköy merasından genel bir görünüm

Mera alanlarında yapılan çalışmalar sırasında ayrıca; başta Lamiaceae familyasına bağlı Glechoma hederacea (yernanesi) gibi bitki türleri olmak üzere, halk arasında şifalı olarak değerlendirilen bitkilerin ilgili mera alanlarına bağlı köylerin yerlisi olmayan kişiler tarafından sökülerek (Şekil 8) meraların bitki çeşitliliğini etkilediği ve hatta bu toplamaların yerli bitkilerin neslinin tükenmesine neden olan risk durumları oluşturduğu belirlenmiştir.

$\mathrm{Bu}$ durum ile ilgili olarak, çalışma alanlarındaki köylerde, hayvan üreticileri başta olmak üzere yerel halk; bitki sökümleri için köylerine gelen insanların mera alanlarında verdikleri zarar sonucu hem bazı bitkilerin popülasyonunu yok olma eşiğine getirdiğini hem de mera alanlarına açılan çukurların kapatılmaması sonucu hayvanların bu çukurlara takılarak yaralandığı ve böylece hayvanlarına dolaylı yoldan zarar verildiği konusunda sorunların ifade etmiş ve bu durumların çözümüne yönelik ilgili kuruluşların yardımlarını beklediklerini vurgulamışlardır.

Mera alanlarında karşılaşılan en yaygın durumlardan biri de mera da beslenen hayvanlar tarafindan taşınan gübrelerdir (hayvan artıkları). Hayvanların gübreleri mera alanlarında yeni bitki popülasyonların oluşmasına ve / veya farklı alanlardan mera alanlarına yeni bitkilerin 
taşınmasına neden olarak (Şekil 9) mera bitki çeşitliliğinde etkili bir rol oynamaktadır. Bu nedenle, mera alanlarında otlayan hayvanların merada otlama zamanları iyi belirlenmeli ve dişarıdan taşınması muhtemel bitki tohumlarına karşı mera otlatma zamanlarının Il Tarım ve Orman Müdürlükleri tarafından belirlenen dönemler dışındaki tarihlerde yapılmaması konusuna titizlikle uyulmalıdır. Ayrıca yeni bulașmalar ile mera alanlarına bulașan yabancı bitkiler mera yönetimi çalışmalarında özellikle dikkate alınmalıdır.
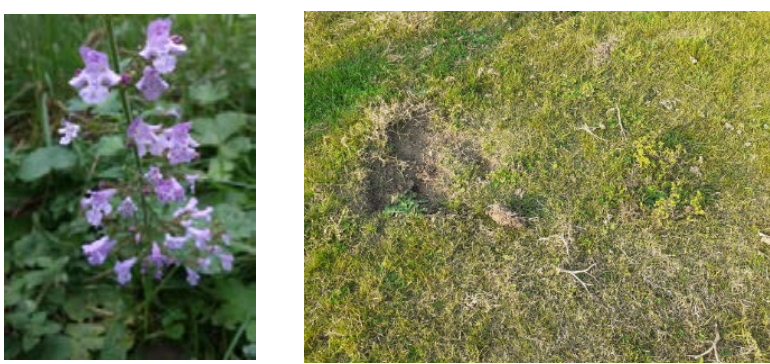

Șekil 8. Glechoma hederacea - Yernanesi bitkisi ve bitkinin sökülmesiyle mera alanında oluşan zarar durumu

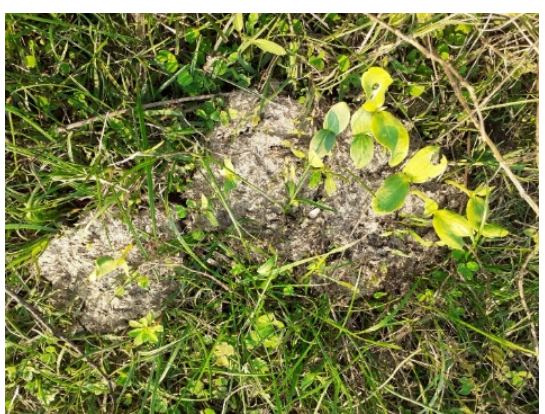

Şekil 9. Hayvan gübresi ile mera alanlarına taşınan ve ilgili alanda çimlenen bitkiler

\section{Sonuçlar ve Öneriler}

Bu çalışma verileri; Düzce ili merkez ilçeye bağlı 12 mera alanının zengin bir bitki kompozisyonuna sahip olmasına rağmen her bir mera alanında toksisite ve yaralanma gibi olumsuz etkilere sahip bitki türlerinin de azımsanmayacak bir durumda olduğunu ortaya koymuştur. Özellikle zehirlenme etkisi nedeni ile mecbur kalınmadıkça ruminantlar tarafından tercih edilmeyen bitkilerin otlatma ile baskı altında tutulamaması ilgili bitkilerin hızla yayılmalarına neden olan faktörler arasında sayılabilir. Örneğin; Oenanthe pimpinelloides, Eryngium campestre, Onopordum acanthium, Xanthium spinosum gibi yüksek etkileri (toksik + yaralanma - Çizelge 2) olan bitkilerin istila potansiyelleri de dikkate alındığında mera bitki kompozisyonları yüksek oranda ve kısa bir süre de ciddi bir şekilde bozulma tehdidi ile karşı karşıyadır. Ancak ilgili mera alanlarında polinatör böcekler ve diğer hayvan grupları için yem değeri olan Lamium purpureum, L. amplexicaule, Taraxacum macrolepium, Medicago arabica, Lotus corniculatus, Senecio vernalis, Trifolium repens, Viola odorata gibi çiçekli bitkilerin tespit edilmiş olması da önem taşımaktadır. Dolayısıyla, Düzce merkez ilçe meralarında karşılașılan bitki türlerinin tüm canlılar (polinatör böcekler, ruminantlar, diğer hayvan grupları ve insanlar) için fayda düzeylerinin arttırılması, mera alanlarının sürdürülebilirliği için yem değeri olan bitki türlerinin korunması ve zararlı olarak değerlendirilen taksonlar başta olmak üzere ilgili alanlara tek tür olarak baskın yayılım sergileyen taksonların yönetimi için gerekli önlemler bir an önce alınmalıdır.

Doğal rezervler olarak tanımlanabilen mera alanlarının sürdürülebilirliği için ilgili alanların yönetiminde; (i) insan faaliyetleri ve (ii) bitki türlerinin etki durumu için gerekli önlemlerin alınması yararlı olacaktır. $\mathrm{Bu}$ durumlar için alınabilecek önlemlere ait öneriler ise genel olarak iki temel madde halinde sunulabilir.

1. Antropojenik etkilerin azaltılması veya ortadan kaldırılması ilk öncelik olmalıdır. Bunun için alınabilecek önlemler;

a. Mera kanunu yüksek yaptırımlar ile uygulanmalı ve mera kanunu uygulamasındaki sorunlara yönelik geliştirilen çözümler (Balabanlı ve ark., 2009) dikkate alınmalıdır.

b. Alan koruma, doğal rezerv alanları olan meralar için olmazsa olmaz ön koşul olmalıdır. Bunun için ilk öncelik mera alanlarının imara açılmasının engellenmesi olmalıdır. Ayrıca bitki istilaları, doğal afetler ve benzeri durumlar için de ilgili alanların korunmasına yönelik zorunlu / güdümlü çalışmalar uygulamaya geçirilebilir.

c. Mera alanlarına zarar veren bitki toplayıcılığına engel olabilecek bir sistem geliştirilebilir. Örneğin; mera alanlarında bitki toplayıcılı̆̆ının yapılmaması gerektiğine yönelik uyarı levhaları mera girişlerine asılabilir. Ayrıca yerel halk Tarım ve Orman İl /İlçe Müdürlükleri gibi kuruluşlara bitki toplayıcılık durumlarını ihbar yolu bildirebilmelidir.

d. Mera kullanım (otlatma rejimi) zamanlarına uyulmalıdır. Aksi durumlar da ise yaptırımlar uygulanmalıdır. Ayrıca "mera otlatma zamanlarının 
e. açılması" gibi başlıklar ile düzenlenebilecek mera şenlikleri ve/veya "kamu spotu" gibi uygulamalar ile halkın meralara karşı duyarlılığı arttırılabilir.

f. Mera alanlarını koruma açısından mera çevresine çekilen çit / tel örgü gibi sınırlayıcı koruma duvarlarının bakım ve onarım işlemleri yapılmalıdır.

2. Bitki türlerinin etki durumlarına göre yönetim çalışmaları yapılmalıdır.

a. Mera alanlarında bulunan bitki türlerinin etki durumlarını inceleyen çalışmalar yürütülebilir.

b. Yüksek etkileri olan bitki türlerine karşı farkındalık faaliyetleri yürütülmelidir. $\mathrm{Bu}$ amaçla yüksek etkileri olan bitki türlerinin tanıtımına yönelik bilgilendirici broşürler köyler /ilçeler / iller bazında dağıtılabilir.

c. Mera alanlarının bulunduğu köyler bazında yöre halkı yönetim çalıșmalarına dâhil edilebilir.

d. Yönetim çalıșmalarının başlatıldığı alanlar düzenli aralıklar ile takip altında tutulmalı ve mera yönetim ilkelerine uygun olarak mera kullanımı sağlanmalıdır.

e. Mera bitki kompozisyonunun düzenlenmesi için mera ıslah çalışmalarına önem verilmelidir. Bunun için öncelikle ortak dil kullanımı için mera yönetimi terimleri doğru kullanılmalı (Yüksek ve ark., 2003) ve mera ıslahı için bölgelere göre başarısı belirlenmiş yöntemler dikkate alınmalıdır.

f. Mera alanlarının ıslahı ve /veya mera alanlarında yüksek yayılım sergileyen türler ile mücadelede gerekli maliyetlerin karşılanması için devlet kurumlarına ayrılan ödenekler arttırılmalıdır. Nitekim mera alanlarında problem teşkil eden taksonlar ve bu taksonların yayılma potansiyelleri başta tarımsal üretimi olmak üzere yüksek çevresel ve sosyoekonomik etkilere neden olabilir (Drscoll ve ark., 2014; Aksan ve ark., 2019).

g. İnsan ve hayvan beslenmesinde önemli bir paya sahip olan Lamiaceae familyasına bağlı bitki türleri (Aksan ve ark., 2019; Yazlık ve ark., 2019; Yazlık ve ark., 2020) başta olmak üzere, mera alanlarında bulunan tüm çiçekli bitkiler polinazasyon sağlayan böcekler (arılar, kelebekler, ... vb.) ve meradan yararlanan diğer tüm hayvan türlerini de kapsayan biyolojik çeşitlilik için özel önem arz eder. Dolayısıyla bu bitkilerin mera alanlarında korunması ve popülasyolarının devamlılığı için mera koruma kanununda meralardan faydalı bitki türlerinin sökülmemesi konusunun önemle işlenmesi yararlı olacaktır.

Düzce merkez ilçe mera alanlarındaki bitki türlerinin ve bu bitkilerin etkilerinin tespitine yönelik ilk kez bu çalışma ile elde edilen verilerin, bölge genelinde yapılabilecek mera ıslahı çalışmalarına bir kaynak ve mera alanlarındaki bitki türlerinin çevresel ve sosyoekonomik etkilerine yönelik farkındalığın arttırılmasına olanak sağlamasını umuyoruz.

\section{Çıkar çatışması}

Yazarlar arasında herhangi bir çıkar çatışması yoktur.

\section{Yazarların katkı beyanı}

UAA: Arazi çalışmalarının yürütülmesi, veri analizleri ve makalenin ilk taslak yazımına katkı sağlamıştır. AY: Araștırma konusunu belirlenmesi, çalışma metodunun oluşturulması, arazi çalışmalarının yürütülmesi, veri analizlerinin kontrolü ve makale yazımı ve son şeklinin verilmesi aşamalarına katkı sağlamıştır.

\section{Teşekkür}

$\mathrm{Bu}$ çalışma Düzce İl Tarım ve Orman Müdürlüğü desteği ile yürütülmüştür. Yazarlar desteğinden dolayı ilgili kuruluşa ve bitki türlerin teşhisi konusunda destek sağlayan Dr. Öğretim Üyesi Neval GÜNEŞ ÖZKAN'a teşekkürlerini sunar.

\section{Kaynaklar}

Aksan, U.A., Kuşkapan, Ö. \& Yazlık, A., (2019). Çayır-mera alanlarındaki yabani bitki türlerinin hayvanlara etkileri. International Conference on Agriculture and Rural Development (ISPEC), Bildiriler Kitabı, 10-12 Haziran, Siirt, pp:16-36.

Aksan,U.A. (2020). Mera alanlarında bulunan bitki türleri ve etkileri: Düzce merkez örneği. Yüksek Lisans Tezi, Fen Bilimleri Enstitüsü, Düzce Üniversitesi, Düzce.

Alay, F., İspirli, K., Uzun, F., Çınar, S., Aydın, İ. \& Çankaya, N. (2016). Uzun Süreli Serbest Otlatmanın Doğal Meralar Üzerine Etkileri. Gaziosmanpaşa Üniversitesi Ziraat Fakültesi Dergisi 33(1): 116-124.

Altın, M., Gökkuş, A. \& Koç, A., (2011). Çayır ve Mera Yönetimi. Tarım ve Köy İșleri Bakanlığı, Tarımsal Üretim ve Geliştirme Genel Müdürlügü Yayınları, 331s., Ankara

Anonim, (2008). Türkiye'nin Çayır ve Mera Bitkileri. Tarım ve Köyişleri Bakanlı̆̆ı. Çayır, Mera, Yem Bitkileri ve Havza Geliştirme Daire Başkanlığı. 466s. 
Asav Ü., Kadıoğlu İ. \& Yanar Y. (2014). Trabzon ili ve ilçelerindeki mera alanlarındaki önemli yabancı ot türleri ile bunların dağılımları ve yoğunluklarının belirlenmesi. Gaziosmanpașa Üniversitesi Ziraat Fakültesi Dergisi 31(1): 29-36.

Balabanlı C., Albayrak S., Türk M.\& Yüksel O. (2006). Türkiye çayır meralarında bulunan bazı zararlı bitkiler ve hayvanlar üzerindeki etkileri. Süleyman Demirel Üniversitesi Orman Fakültesi Dergisi A(2): 89-115.

Balabanlı, C., Albayrak S., Türk M. \& Yüksel O. (2009). 4342 Sayılı mera kanunu uygulamasında karşılaşılan sorunlar ve çözüm yolları. Turkish Journal of Forestry 1(0): 75-81.

Benthien, O., Braun, M., Riemann, J. C. \& Stolter, C. (2018). Long-term effect of sheep and goat grazing on plant diversity in a semi-natural dry grassland habitat. Heliyon 4(3):e00556.

Bilgen M. \& Özyiğit Y., (2005). Korkuteli ve Elmalı'da Bulunan Bazı Doğal Meraların Vejetasyon Durumlarının Belirlenmesi. Akdeniz Üniversitesi Ziraat Fakültesi Dergisi 18(2): 261-267.

Carvell, C. (2002). Habitat use and conservation of bumblebees (Bombus spp.) under different grassland management regimes. Biological Conservation 103(1): 33-49.

Çaçan, E. \& Yüksel, A. (2016). Çayır ve Meraların Bölgesel Kalkınma Üzerindeki Etkisi. ÜNIDAP Uluslararası Bölgesel Kalkınma Konferansı, Bildiriler Kitabı, 2830 Eylül 2016, Muş, pp:521-531.

Çetiner, M., Genç, S. \& Gökkuş, A. (2015). Biga (Çanakkale) ilçesi Gerlengeç köyü mera ıslahı ve yönetimi çalışması. Tarla Bitkileri Kongresi, Bildiriler Kitabı II, 7-10 Eylül 2015, Çanakkale, pp: 63-67.

Çınar S., Hatipoğlu R., Avcı M., İnal İ. \& Yücel C. (2018). Adana İli Tufanbeyli İlçesi meralarının botanik kompozisyonunun belirlenmesi üzerine bir araştırma. Türk Doğa ve Fen Dergisi 7(2): 21-29.

Davis PH (Ed.) (1965-1985) Flora of Turkey and the East Aegean Islands, Vol. 1 (1965), Vol.2 (1967), Vol. 3 (1970), Vol. 4 (1972), Vol. 5 (1975), Vol. 6 (1978), Vol. 7 (1982), Vol.8 (1984), Vol. 9 (1985). Edinburgh University Press, Edinburgh.

Davis PH, Mill RR, Tan K (Eds) (1988) Flora of Turkey and the East Aegean Islands, Vol. 10.Edinburgh University Press, Edinburgh.

Demir, A.Ö., Kor, D. \& Çelen, A.E. (2010). Türkiye 'de Mera Koşullarında Beslenen Küçükbaş Hayvanların Karşılaşması Olası Bazı Zehirli Bitkiler ve Zehirlenme Belirtileri. Y.Y.Ü. Fen Bilimleri Enstitüsü Dergisi 15(1): 54-58

Demir, E. \& İptaş S., (1996). Merada otlayan evcil ruminantlarda ortaya çıkan beslenme bozuklukları ve zehirlenmeler. Türkiye 3. Çayır-Mera ve Yem
Bitkileri Kongresi, 17-19 Haziran, 179-185, Erzurum

Deveci, M., Cinbırtoğlu, Ș. \& Demirkol, G. (2015). İlkbahar dönemi bitkileri ve arıcılıkta polen kaynağı bakımından önemi. Akademik Ziraat Dergisi 4(1): 112.

Driscoll D.A., Catford J.A., Barney J.B., Hulme P.H., Inderjit, Martin T.G., Pauchard A., Pyšek P., Richardson D.M., Riley S. \& Visser V. (2014). New pasture plants intensify invasive species risk. 111(46):1662216627.

GBIF, (2020). GBIF Backbone Taxonomy. Checklist dataset https://www.gbif.org/ (Erişim tarihi, 10.05.2019)

Gür, M. (2007). Yörükler Köyü Doğal Mera Vejetasyonunun Botanik Kompozisyonu ve Verim Potansiyeli Üzerinde Bir Araștırma. Yüksek Lisans Tezi, Fen Bilimleri Enstitüsü, Namık Kemal Üniversitesi, Tekirdağ.

Gür, M. \& Altın, M. (2015). Trakya yöresinde farklı kullanım geçmişine sahip meraların florastik kompozisyonlarının bazı özellikleri. Anadolu Tarım Bilimleri Dergisi 30: 60-67.

Güner, A., Özhatay, N., Ekim, T. \& Başer, K.H.C. (2000). Flora of Turkey and the East Aegean Islands. Edinburg University Press, Vol: 11.

Güner, A., Aslan, S., Ekim, T., Vural, M. \&Babaç, M.T. (edlr.), (2012). Türkiye Bitkileri Listesi (Damarlı Bitkiler). Nezahat Gökyiğit Botanik Bahçesi ve Flora Araştırmaları Derneği Yayını. İstanbul.

Gökkuş, A. (2016). Meralarımız ile ilgili bir değerlendirme. TÜRTOB Dergisi 25: 6-8.

Hatipoğlu, R., Tükel, T. \& Atıș, İ. (2006). Çayır-Mera Bitki Topluluklarında Allelopati. Allelopati Çalıștayı, Bildiri Kitabı, Yalova, pp:323-338.

Holechek, J. (2001). A growing population, rangelands and the future. Rangelands 23(6): 39-43.

Kara, A, Çakal, Ş, Tavlaş, A, Yazıcı, A, Aygün, C \& Avağ, A. (2012). Kuzeydoğu Anadolu'da çayır ve mera kullanımı ile ilgili alıșkanlıklar ve problemler. Alinteri Journal of Agriculture Science 16(1): 7-18.

Karan, H. \& Başbağ, M. (2017). Elazığ ili merkez ilçesi hal köyü'nde korunan ve otlatılan alanların botanik kompozisyon bakımından karşılaștırılması. Fırat Üniversitesi Mühendislik Bilimleri Dergisi 29(2): 259-264.

Kleppel, G.S. \& LaBarge, E. (2011). Using sheep to control purple loosestrife (Lythrum salicaria). Invasive Plant Science and Management 4(1): 50-57.

Keeler, R.F., Baker, D.C. \& Evans, J.O. (1988). Individual Animal Susceptibility and Its Relationship to Induced Adaptation or Tolerance in Sheep to Galega officinalis L. Veterinary and Human Toxicology. 
Kușkapan, Ö., (2019). Çayır - Mera alanlarında hayvanlara zararlı yabani otlar ve etkileri. Diploma Bitirme Tezi, Düzce Üniversitesi Ziraat Fakültesi, Düzce.

Kuşvuran, A., Nazlı, R.İ. \& Tan, V. (2011). Türkiye'de ve Batı Karadeniz Bölgesi'nde çayır-mera alanları, hayvan varlığı ve yem bitkileri tarımının bugünkü durumu. Gaziosmanpaşa Üniversitesi Ziraat Fakültesi Dergisi. 28(2): 21-32.

IPBES (2019). Global assessment report on biodiversity and ecosystem services of the Intergovernmental Science-Policy Platform on Biodiversity and Ecosystem Services. E. S. Brondizio, J. Settele, S. Díaz, and H. T. Ngo (editors).

IPNI, (2020). International Plant Name Index. https://www.ipni.org/ (Erişim tarihi, 19.05.2019)

Lubenov, Y. (1985). Zararlı otlar yașam ve ölüm kaynağıdır. Makaklı-Dinçer Yayınları. 175 s.

Öztürk, M., Uysal, I., Gücel, S., Mert, T., Akçicek, E. \& Çelik, S. (2008). Ethnoecology of poisonousplants of Turkey and northern Cyprus. Pakistan Journal of Botany 40(4): 1359-1386.

Özyazıcı, M. \& Yıldız, A. (2017). Türkiye'nin doğusunda yer alan doğal bir meranın toprak ve bitki örtüsünün beslenme dinamiği. Kahramanmaraş Sütçüimam Üniversitesi Doğa Bilimleri Dergisi 20: 109-115.

Seydoşoğlu, S. \& Kökten, K. (2018). Batman ili beşiri ilçesi mera vejetasyonlarının bazı özellikleri. Ege Üniversitesi Ziraat Fakültesi Dergisi 55 (4):491-497

Sullivan, C.A., Skeffington, M.S., Gormally, M.J. \& Finn, J.A. (2010). The ecological status of grasslands on lowland farmlands in western Ireland and implications for grassland classification and nature value assessment. Biological Conservation 143(6):1529-1539.

Sürmen, M., Yavuz, T., Sürmen, B. \& Kutbay, G. (2015). Samsun ili çayır ve mera alanlarında istilacı türlerin tespiti ve yoğunluklarının belirlenmesi. Herboloji Dergisi 18(1): 1-5.

Tepe, I. (1998). Türkiye'de tarım ve tarım dışı alanlarda sorun olan yabancı otlar ve mücadeleleri. II. Baskı. Yüzüncü Yıl Üniversitesi Ziraat Fakültesi Yayınları No: 18, Van.

Terzioğlu, Ö. \& Yalvaç, N. (2004). Van yöresi doğal meralarında otlatmaya başlama zamanı, kuru ot verimi ve botanik kompozisyonun belirlenmesi üzerine araştırma. Yüzüncü Yll Üniversitesi Ziraat Fakültesi Tarım Bilimleri Dergisi 14(1): 23- 26.

Töngel, M.Ö. \& Ayan, İ. (2005). Samsun ili çayır ve meralarında yetișen bazı zararlı bitkiler ve hayvanlar üzerindeki etkileri. Ondokuz Mayıs Üniversitesi Ziraat Fakültesi Dergisi 20(1):84-93.

TUIK, (2016). Bitkisel üretim istatistikleri. T.C. Başbakanlık, Türkiye İstatistik Kurumu (TUIKK),
http://www.tuik.gov.tr/PreTablo.do?alt_id=1001 (Erişim tarihi, 11.10.2019).

TUİK, (2018). Nüfus Projeksiyonları, 2018-2080. Haber Bülteni, Sayı: 30567. http://www.tuik.gov.tr/ (Erişim tarihi, 15.12.2020).

Tükel, T. \& Hatipoğlu, R. (2001). Çayır-meralarda zehirli bitkiler ve hayvanlar üzerindeki etkileri. http://www.tarim.gov.tr (Erişim tarihi, 10.05.2019)

Tüzemen, N. (2018). Türkiye'de besi ve et üretiminde ihracat potansiyeli. Kastamonu University Journal of Engineering and Sciences 4 (2): 5-14.

USDA, (2020). Agricultural Research Service (ARS). https://plants.usda.gov (Erişim tarihi, 9.05.2019)

Ünal, S., Mutlu, Z., Mermer, A., Urla, Ö., Ünal, E. Aydoğdu, M., Dedeoğlu, F., Özaydın, K.A., Avağ, A., Aydoğmuş, O., Şahin, B. \& Serdar, A. (2012a). Ankara İli meralarının değerlendirilmesi üzerine bir çalışma. Tarla Bitkileri Merkez Araştırma Enstitüsü Dergisi 21(2): 41-49.

Ünal, S., Mutlu, Z., Mermer, A., Urla, Ö., Ünal, E., Özaydın, K. A., Avağ, A., Yıldız, H., Aydoğmuș, O., Şahın, B. \& Arslan, S. (2012b). Çankırı İli meralarının mera durumu ve sağlığının belirlenmesi üzerine bir çalışma. Tarım Bilimleri Araştırma Dergisi 5(2): 131-135.

Yavuz, R. (2013). Mera ıslahında herbisit ve gübre uygulamaları (Düzce Köprübaşı̈merefendi Örneği). Doktora Tezi, Fen Bilimleri Enstitüsü, Düzce Üniversitesi, Düzce.

Yazlık, A., Ulutaș, O., Haliloğlu, A., Balcı, A., Sazak, A., Çelik, S. \& İspaha, İ. (2019). Yaşayan alan: Prusias ad Hypium antik kentinde yabani ot türleri. Düzce Üniversitesi Bilim ve Teknoloji Dergisi 7 (3), 19091921.

Yazlık, A., Kavak, M., Aşkın, E., Külcüoğlu, N., Ersoy, Ö., Kovankaya, F., Demirtaş, E. \& Aydoğdu A. (2020). Kentsel yaşam alanında bitki çeşitliliği ve etkileri: Düzce Üniversitesi Konuralp kampüsü örneği. Türkiye Tarımsal Araştırmalar Dergisi 7(1): 66-77.

Yıldız A. \& Özyazıcı M.A. (2017). Karasal iklim kuşağında bulunan bir meranın farklı yöneylerinde botanik kompozisyonun, ot verimi ve ot kalitesinin belirlenmesi. Türkiye Tarımsal Araștırmalar Dergisi 4(3): 218-231.

Yllmaz, M. (2018). Toxic - Hazardous substances found in plants in a natural pasture protected from grazing and their effects on animals. Akademik Platform Mühendislik ve Fen Bilimleri Dergisi 6(1): 97-103.

Yüksek, T., Yüksek F. \& Eminağaoğlu Ö. (2003). Bazı mera amenajmanı terimleri ve tanımlamaları. Kafkas Üniversitesi. Artvin Orman Fakültesi Dergisi 1(2): 21-32. 